\title{
Mineralogy and Distribution of Critical Elements in the Sn-W-Pb-Ag-Zn Huanuni Deposit, Bolivia
}

\author{
Andreu Cacho ${ }^{1}$, Joan-Carles Melgarejo ${ }^{1}{ }^{1}$, Antoni Camprubí ${ }^{2, *}$, Lisard Torró ${ }^{3}{ }^{(0)}$, \\ Montgarri Castillo-Oliver ${ }^{4}$, Belén Torres ${ }^{1}$, David Artiaga ${ }^{5}$, Esperança Tauler ${ }^{1}{ }^{1}$, \\ Álvaro Martínez ${ }^{6}$, Marc Campeny ${ }^{1,7}$, Pura Alfonso ${ }^{8}$ and Osvaldo R. Arce-Burgoa ${ }^{9,10}$
}

1 Departament de Mineralogia, Petrologia i Prospecció Geològica, Facultat de Ciències de la Terra, Universitat de Barcelona, Carrer de Martí i Franquès s/n, 08028 Barcelona, Spain; acachoamgeo@gmail.com (A.C.); joan.carles.melgarejo.draper@ub.edu (J.-C.M.); belentcgeo@gmail.com (B.T.); esperancatauler@ub.edu (E.T.); mcampenyc@bcn.cat (M.C.)

2 Instituto de Geología, Universidad Nacional Autónoma de México, Ciudad Universitaria, Coyoacán, 04510, CDMX, Mexico

3 Geological Engineering Program, Faculty of Sciences and Engineering, Pontifical Catholic University of Peru (PUCP), Av. Universitaria 1801, San Miguel, Lima 15088, Peru; lisardtorro@hotmail.com

4 ARC Centre of Excellence for Core to Crust Fluid Systems (CCFS) and GEMOC, Department of Earth and Planetary Sciences, Macquarie University, North Ryde, NSW 2109, Australia;

montgarri.castillo-oliver@mq.edu.au

5 Centres Científics i Tecnològics, Universitat de Barcelona, Carrer de Martí i Franquès s/n, 08028 Barcelona, Spain; artiaga@ccit.ub.edu

6 Departement des Sciences de la Terre, Université de Genève, Rue des Maraîchers 13, 1205 Genève, Switzerland; alvaro@bizkaia.eu

7 Departament de Mineralogia, Museu de Ciències Naturals de Barcelona, Passeig Picasso s/n, 08003 Barcelona, Spain

8 Departament d'Enginyeria Minera, Industrial i TIC, Escola Tècnica Superior d'Enginyeria de Mines de Manresa, Universitat Politècnica de Catalunya, Avinguda de les Bases de Manresa 61-73, 08242 Manresa, Spain; maria.pura.alfonso@upc.edu

9 Colegio de Geólogos de Bolivia, Edificio Señor de la Exaltación Nro. 4683, Av. Hernando Siles entre calles 1 y 2, Zona de Obrajes, Casilla 8941, La Paz, Bolivia; info@osvaldoarce.com

10 Eloro Resources Ltd. Av. La Floresta 497, Of. 101, San Borja, Lima 15037, Peru

* Correspondence: camprubitaga@gmail.com or camprubi@comunidad.unam.mx; Tel.: +52-555-622-4310 (ext. 128)

Received: 28 August 2019; Accepted: 28 November 2019; Published: 4 December 2019

Abstract: The polymetallic Huanuni deposit, a world-class tin deposit, is part of the Bolivian tin belt. As a likely case for a "mesothermal" or transitional deposit between epithermal and porphyry Sn types (or shallow porphyry Sn), it represents a case that contributes significantly to the systematic study of the distribution of critical elements within the "family" of Bolivian tin deposits. In addition to $\mathrm{Sn}, \mathrm{Zn}$ and $\mathrm{Ag}$, further economic interest in the area resides in its potential in critical elements such as In, Ga and Ge. This paper provides the first systematic characterisation of the complex mineralogy and mineral chemistry of the Huanuni deposit with the twofold aim of identifying the mineral carriers of critical elements and endeavouring plausible metallogenic processes for the formation of this deposit, by means of a multi-methodological approach. With In concentrations consistently over $2000 \mathrm{ppm}$, the highest potential for relevant concentrations in this metal resides in widespread tin minerals (cassiterite and stannite) and sphalerite. Hypogene alteration assemblages are hardly developed due to the metasedimentary nature of host rocks, but the occurrence of potassium feldspar, schorl, pyrophyllite and dickite as vein material stand for potassic to phyllic or advanced argillic alteration assemblages and relatively high-temperature (and low $\mathrm{pH}$ ) mineralising fluids. District-scale mineralogical zonation suggests a thermal zonation with decreasing temperatures from the central to the peripheral areas. A district-scale zonation has been also determined for ${ }^{34} \mathrm{~S}_{\mathrm{VCDT}}$ values, which range $-7.2 \%$ o to $0.2 \%$ o (mostly $-7 \%$ o to $-5 \%$ ) in the central area and $-4.2 \%$ o to $1.0 \%$ o 
(mainly constrained between $-2 \%$ ond $1 \%$ ) in peripheral areas. Such values stand for magmatic and metasedimentary sources for sulfur, and their spatial zoning may be related to differential reactivity between mineralising fluids and host rocks, outwardly decreasing from the central to the peripheral areas.

Keywords: critical elements; indium; gallium; germanium; tin; silver; cerium; hydrothermal; bolivian tin belt

\section{Introduction}

The Huanuni $\mathrm{Sn}-\mathrm{W}-\mathrm{Pb}-\mathrm{Ag}-\mathrm{Zn}$ deposit is the largest tin producer in Bolivia and, alongside the San Rafael deposit in Peru, spearheads the tin production in the world. The 2017 production was 8415 tonnes of tin and, despite a fall in production below 7000 tons in 2018, the tin production in Huanuni still accounts for over a half of the total production of Bolivia. These deposits belong to the Bolivian Tin (Sn-W-Ag-Sb-Bi) Belt (Figure 1) that has significant critical metal resources (In, Ge and Ga [1-10]). Increasing international demand is envisaged for In, Ge and Ga, particularly in emerging technologies such as the production of photovoltaic cells (In and Ga), optical fibre and infrared optical technologies (Ge). In addition, these metals are listed as Critical Raw Materials for the European Union [11], which attests to their strategic importance due to the large share in their supply by China-By far, the largest global producer of In, Ga and Ge.

The Andean cordillera contains four metallogenic belts from west to east, these are the Fe, porphyry $\mathrm{Cu}-\mathrm{Mo}(-\mathrm{Au}), \mathrm{Cu}-\mathrm{Pb}-\mathrm{Zn}-\mathrm{Ag}$, and $\mathrm{Sn}-(\mathrm{W}-\mathrm{Ag}-\mathrm{Sb}-\mathrm{Bi})$ belts [3], the last of which is commonly referred as the "Tin Belt". The Tin Belt extends between southeast Peru and the northernmost tip of Argentina, and most of it sits on western Bolivia (Figure 1). The Oruro region in southwest Bolivia is located on the central part of the Tin Belt, at the hinge between the northerly NW-SE part of the belt and the southerly $\mathrm{N}-\mathrm{S}$ part (Figure 1). This region contains some of the most outstanding tin deposits in the world, which correspond to various types or models of formation. Despite its major economic importance, only a few studies are available on the Huanuni deposit [12-17]. Early studies [12-14] determined the essential characteristics of this deposit, including its general features, structural configuration, mineralogy, and ore distribution. To the extent of the existing literature, the formation of the Huanuni deposit is not clearly ascribed to any existing model of formation or type of deposits. The Bolivian Tin Belt is constituted by Upper Triassic to Lower Jurassic, and Miocene to Pliocene major epochs in association with subalkaline peraluminous S-type magmatism [18-20]), and the possible association of the Huanuni deposits with Miocene intrusive rocks is not addressed in this paper.

The present study aims at the determination of the distribution of critical metals in the Huanuni deposit in the light of the time and space distribution of the minerals that bear them. This includes the determination of its paragenetic sequence and differences in the mineralogy of central to distal portions of the deposit. This one corresponds to a group of papers of various Bolivian tin deposits with the same collective aim. 


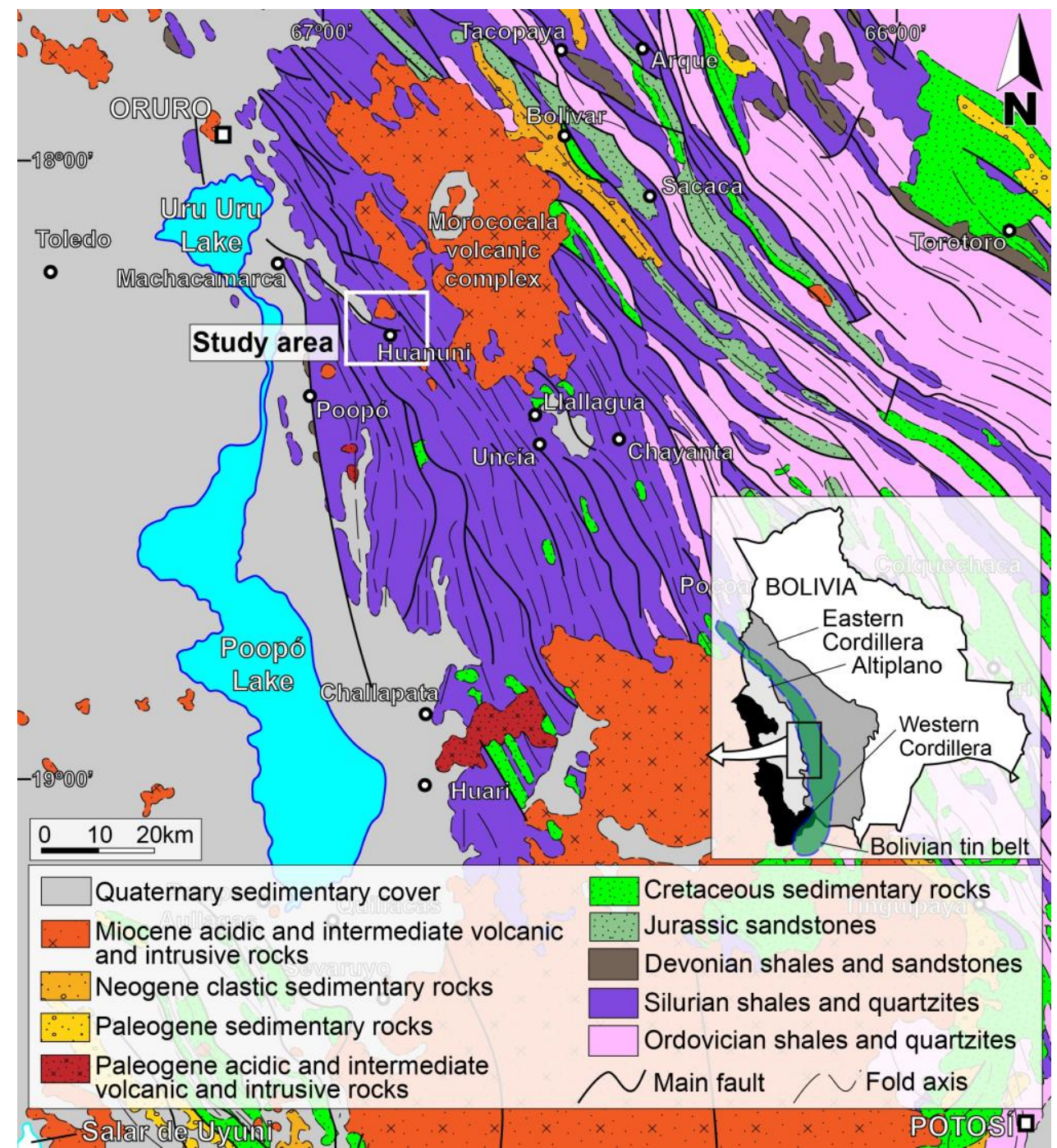

Figure 1. Regional geological map showing the location of the study area (Huanuni deposit: white box). Inset shows the location of the map within the Eastern Cordillera (Andean morphotectonic units are after Arce-Burgoa [21] and the distribution of the Bolivian Tin Belt is after Mlynarczyk and Williams-Jones [3]).

\section{Geology}

The Huanuni district (Oruro department, Pantaleón Dalence province) is located $275 \mathrm{~km}$ SE of $\mathrm{La} \mathrm{Paz}$, in the central part of the Eastern Cordillera of the Bolivian Andes (Figure 1). The Eastern Cordillera is composed of Ordovician to Cretaceous sedimentary sequences, comprising thick black shales, siltstones, limestones, sandstones, slates and quartzites (Figures 1 and 2; [22]). These were regionally affected by NNW-SSE striking fault and fold systems [23], possibly due to the Famatinian orogeny and reactivated during the Andean. The sedimentary package is affected by low-grade regional metamorphism related to the Famatinian orogeny. Intrusions of Miocene acid stocks and domes occur in the central part of the Eastern Cordillera, and they are partly covered by ignimbrites, which are late Miocene in age [22,24-27].

The mineralisation in the Huanuni deposit is largely hosted by quartzites, shales and siltstones of the Paleozoic Llallagua, Uncía and Cancañiri formations and, to a lesser extent, by the pyroclastic and lava series of the Miocene Morococala Formation [28], around the Pozokoni hill (Figure 2). The Cancañiri Formation (Ashgill) consists of laminated diamictites, sandstones and mudstones that attain about $1500 \mathrm{~m}$ in thickness and are a product of glacial-fluvial formation within an extensional 
regime $[29,30]$. The Llallagua Formation consists of sandstones and quartzites with intercalated mudstones and limolites that attain about $1500 \mathrm{~m}$ in thickness and underlies the Uncía Formation [31]. The early Uncía Formation (Wenlock to Ludlow) consists of laminated shales that were deposited during a marine transgression.

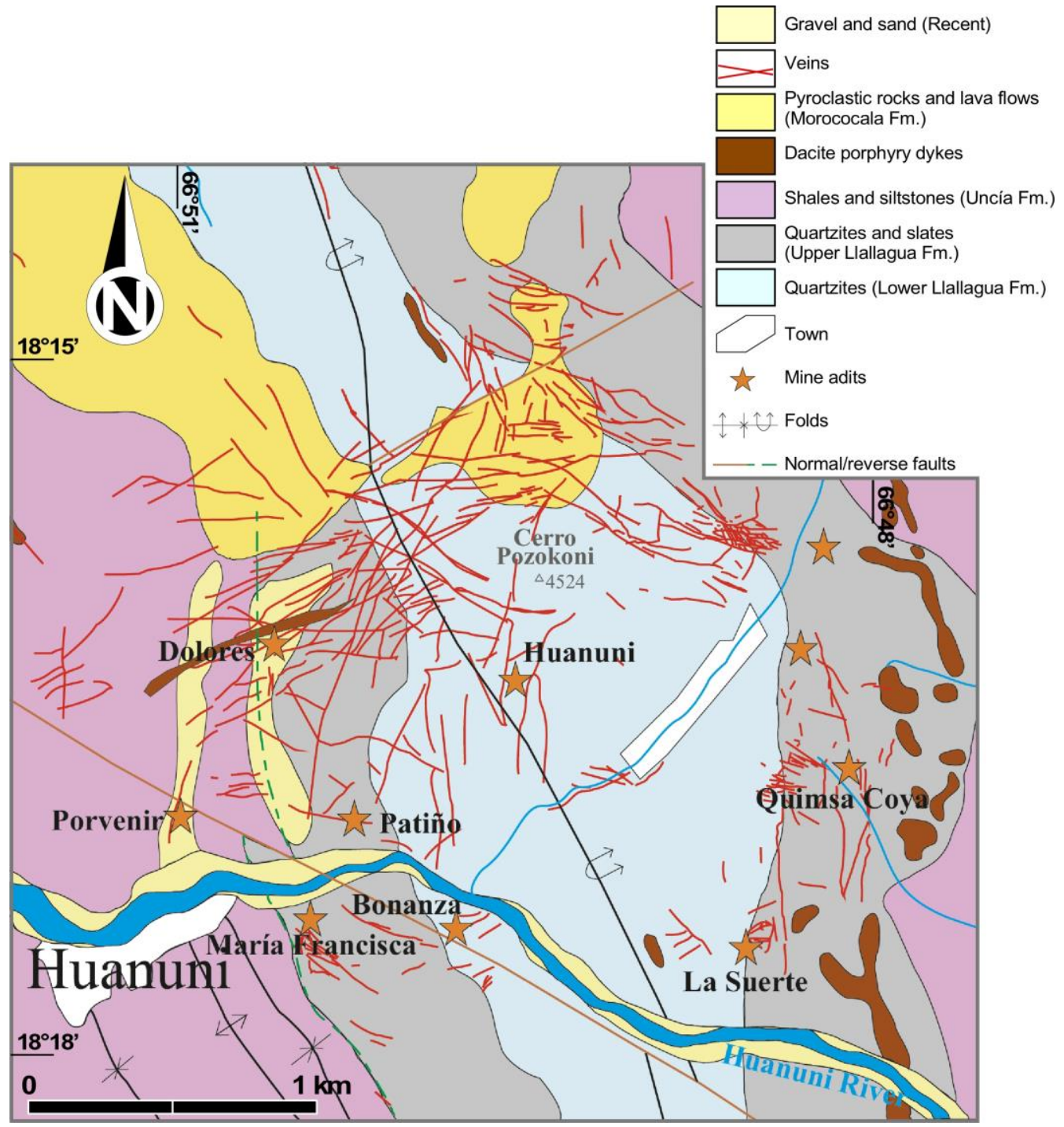

Figure 2. Local geological map of the ore deposits at Huanuni, in which mineralised bodies are indicated upon aerial photo interpretation of this area. Modified from Cacho et al. [32].

The polymetallic deposits are found dominantly on the eastern flank and the nucleus of the locally overturned (towards the SW) Pozokoni anticline and are hosted by rocks of the Llallagua and Uncía formations [31]. Miocene porphyric dikes, approximately N-S striking, crop east of the Pozokoni anticline and extend for over $2 \mathrm{~km}$ (Figure 2). These are inferred as the most likely source for the hydrothermal polymetallic deposits [21]. A similar dike also occurs at the Dolores mine, on the western side of the mining district, striking WSW-ENE and over $500 \mathrm{~m}$ long, and a smaller one on the northern part of the district. All these dikes occur peripherally to the mineralised area. Nevertheless, the occurrence of a blind intrusion below Cerro Pozokoni (Huanuni mine; Figure 2) within the core of the homonymous anticline is inferred [21].

The Huanuni deposit consists of several tens of veins and breccias with no preferential orientation [12] but having roughly concentric and radial patterns, thus resembling a radial nested arrangement (Figure 2). However, we may tentatively sort the veins into three main families: (A) $110^{\circ}$ 
(e.g., Veta Grande, Oriente, Nueva, Chuallani or Progreso veins), (B) $160^{\circ}$ (e.g., Norteña or Cruzera vein), and (C) between $045^{\circ}$ and $080^{\circ}$ (e.g., Esperanza and Amarilla veins). In this study, we group the veins into three main domains, a central domain around the Huanuni mine and Pozokoni hill, and two peripheral or distal domains named Bonanza and La Suerte (south and southeast of the central domain, respectively). The peripheral zones are richer in $\mathrm{Zn}$ relative to the central. The veins are normally less than $1 \mathrm{~m}$ thick, e.g., the Veta Grande vein is up to $50 \mathrm{~cm}$ thick, veins in the La Suerte area are $10 \mathrm{~cm}$ to $70 \mathrm{~cm}$ thick, and about $25 \mathrm{~cm}$ thick in the Bonanza area. The mineralised areas extend across a $\sim 10 \mathrm{hm}^{2}$ quadrangle (Figure 2). Most veins do not crop out but their tops are found between $100 \mathrm{~m}$ and $350 \mathrm{~m}$ below the Pozokoni hill summit, and some of them occur even deeper ( $480 \mathrm{~m}$ below the summit height). This attests to some potential of undiscovered mineralised structures [21]. The mineralised structures are crudely banded and include early quartz and tourmaline followed by cassiterite, and then by various generations of ore associations [13]. The available data from fluid inclusions in this deposit indicate the occurrence of saline brines up to $26 \mathrm{wt}$ \% $\mathrm{NaCl}$ equiv., homogenisation temperatures up to $425{ }^{\circ} \mathrm{C}$, and many metals dissolved in inclusion fluids, including Sn and Ge [15,17,31].

\section{Methodology}

A total of 42 in situ surface and gallery samples were obtained, including 31 samples from the Huanuni mine, six from the La Suerte Mine and five from the Bonanza mine. Samples were studied in thin $(n=3)$ and thick $(n=19)$ polished sections by means of transmitted- and reflected-light petrography, X-ray diffraction (XRD), Raman microspectroscopy, scanning electron microscopy with energy analyser (SEM-EDS), electron probe microanalysis (EPMA), and laser ablation inductively coupled plasma mass spectrometry (LA-ICP-MS). Except for the ICP-MS analyses, the rest were carried out at the Centres Científics i Tecnològics of the Universitat de Barcelona.

The XRD equipment was a PANalytical XPert PRO MPD (Almelo, The Netherlands/Malvern, UK) alpha1 diffractometre with a focaliser primary monochromator and an Xcelerator detector. The radiation used was $\mathrm{Ko1} \mathrm{Cu}(\lambda=1.5406 \AA)$ at $45 \mathrm{kV}$ and $40 \mathrm{~mA}$. Spectra were interpreted by means of the PANalytical XPert JCPDS.

A dispersive spectroscope Horiba Jobin Yvon LabRam 800 (Horiba, Tokyo, Japan) was used for mineral identification by means of Raman microspectroscopy. A laser with a wavelength of $532 \mathrm{~nm}$ and a beam diameter of $2 \mu \mathrm{m}$ was used; the acquisition time for each analysis was $10 \mathrm{~s}$.

The SEM-EDS equipment was an ESEM Quanta 200 FEI XTE 325/D8395 (Hitachi, Tokyo, Japan) electron microscope with an INCA Energy 250 EDS detector attached. The equipment was operated at 20-25 keV, $1 \mathrm{nA}$ and at a working distance of $10 \mathrm{~mm}$.

The EPMA equipment was a Cameca SX-50 (Cameca, Gennevilliers, France) with four WDS spectrometres and EDS at $20 \mathrm{keV}$ and beam current of $15 \mathrm{nA}$. The analytical programs and standards were pyrite (S, PET, K $\alpha$ ), FeS 2 (Fe, LIF, K $\alpha$ ), Co (Co, LIF, K $\alpha$ ), NiO (Ni, LIF, K $\alpha$ ), GaAs (As, TAP, L $\alpha$ ), and $\mathrm{InSb}(\mathrm{Sb}, \mathrm{PET}, \mathrm{L} \alpha)$ for analyses on arsenopyrite; rutile (Ti, PET, $\mathrm{K} \alpha), \mathrm{Fe}_{2} \mathrm{O}_{3}(\mathrm{Fe}, \mathrm{LIF}, \mathrm{K} \alpha), \mathrm{Nb}(\mathrm{Nb}$, PET, L $\alpha)$, InSb (In, PET, L $\alpha)$, cassiterite (Sn, PET, L $\alpha)$, and Ta (Ta, LIF, L $\alpha)$ for analyses on cassiterite; sphalerite (S, PET, K $\alpha$ ), FeS 2 (Fe, LIF, K $\alpha$ ), sphalerite (Zn, LIF, K $\alpha$ ), CdS (Cd, PET, L $\alpha$ ), and InSb (In, PET, L $\alpha$ ) for analyses on sphalerite; $\mathrm{FeS}_{2}(\mathrm{~S}, \mathrm{PET}, \mathrm{K} \alpha), \mathrm{FeS}_{2}(\mathrm{Fe}, \mathrm{LIF}, \mathrm{K} \alpha)$, chalcopyrite $(\mathrm{Cu}, \mathrm{LIF}, \mathrm{K} \alpha)$, sphalerite (Zn, LIF, K $\alpha$ ), Ge (Ge, LIF, K $\alpha$ ), GaAs (As, TAP, L $\alpha), \mathrm{Ag}_{2} \mathrm{~S}$ (Ag, PET, L $\alpha$ ), CdS (Cd, PET, L $\left.\alpha\right)$, InSb (In, PET, L $\alpha$ ), cassiterite (Sn, PET, L $\alpha)$, InSb (Sb, PET, L $\alpha), \operatorname{PbS}(\mathrm{Pb}, \mathrm{PET}, \mathrm{M} \alpha)$, and Bi $\mathrm{S}_{3}(\mathrm{Bi}, \mathrm{LIF}$, $\mathrm{L} \alpha$ ) for analyses on sulphosalts.

LA-ICP-MS analyses were carried out with a Photon-Machines Excite $193 \mathrm{~nm}$ excimer laser system coupled to an Agilent 7700x (Agilent Technologies, Santa Clara, CA, USA) ICP-MS mass spectrometer at Macquarie University Geochemical Analysis Unit (GAU) (Australia). Calibration of the instrument was done using a NIST610 standard and the values of $\mathrm{Cu}$ and Bi of minerals that were previously analysed by EPMA [33]. Each analysis of stannite and arsenopyrite was normalised to the $S$ contents determined by the electron microprobe, whereas cassiterite analyses were normalised against Sn. The counting time for each analysis was $90 \mathrm{~s}$, including $30 \mathrm{~s}$ of background and $60 \mathrm{~s}$ of 
sample acquisition. In all analysis, the repetition rate of the laser beam was $10 \mathrm{~Hz}$, and its energy density, $70 \%\left(6.5 \mathrm{~J} / \mathrm{cm}^{2}\right)$. To monitor the accuracy of the measurements, the BCR-2 standard was also analysed as a secondary standard. The samples were analysed in runs of 15 analyses, comprising 10 analysis of unknowns, bracketed by two analyses of the NIST610 at the beginning and the end of each run, as well as one analysis of the BCR external standard after the first set of NIST610. The detection limits for REE, Ba, Rb, Th, U, Nb, Ta, Pb, Sr, Zr, Hf, Ti, Y and Ga span 10 ppb to 20 ppb, for Sc and V $100 \mathrm{ppb}$, and for Ni 2 ppm. The accuracy for each analysis ranges between 1 and $10 \mathrm{wt}$. \%, and the spot diameter ranged between $14 \mu \mathrm{m}$ and $40 \mu \mathrm{m}$. Data reduction was carried out online by using the GLITTER software [34,35]. The data are displayed in Table S2 (the full extent of analysed elements). The absolute values for trace elements presented in this manuscript should be taken with caution, given the different nature of the standards and the samples. However, previous works have shown that good accuracy and precision can be obtained during the analysis of sulphides by LA-ICP-MS using the NIST610 standard [36]. Their research included repeated LA-ICP-MS analysis of a PS-1 (sulphide standard) and obtained values comparable ( $<5 \%$ error) to those resulting from solution [37].

Sulphur isotopes analyses were carried out in situ in 30 single grains of sulphide minerals. Pyrite, pyrrhotite, sphalerite and galena grains were separated by careful hand picking under a binocular microscope. Samples were analysed with a continuous flow mass spectrometer Delta C Finnigan MAT coupled with an elemental analyser TC-EA Carlo Erba 1108, at the Centres Científics i Tecnològics of the Universitat de Barcelona. The results are expressed in the delta notation as per mil deviations of the Vienna-Canyon Diablo Troilite (VCDT) standard and the standard deviation is determined to be $0.2 \%$. The results were calibrated by using the IAEA S1, IAEA S2, IAEA S3 and NBS-123 international reference standards.

\section{Mineralogy}

\subsection{Alteration and Gangue Minerals}

Hydrothermal alteration assemblages are poorly developed in host rocks (mainly quartzites, sandstones and shales) due to the low reactivity between them and hydrothermal fluids. Therefore, their spatial distribution cannot be clearly determined from the currently available surface and underground exposures, although indicated widespread silicification and quartz-sericite alteration, with less consistent argillic alteration, pyritization and tourmalinization [38]. Quartz, schorl, potassium feldspar (not adularia), "sericite" (essentially fine-grained muscovite), chlorite (chamosite), epidote, calcite, and kaolinite are more conspicuous as vein material than as alteration minerals in host rocks (Figure 3). Alunite, dickite, halloysite and nacrite, although not found in this study, have been also reported [16,39]. Monazite-(Ce) is strongly associated with "sericite", and stetindite with chlorite. The occurrence of potassium feldspar as vein material may stand for potassic alteration assemblages. Pyrophyllite has been identified by XRD in the central sector in our study and indicates the occurrence of advanced argillic alteration. Kaolinite also occurs as a late alteration mineral, possibly as part of argillic alteration assemblages. "Sericite" is commonly observed in association with quartz and sulphides (Figure 3A), and may occur replacing previously formed hydrothermal potassium feldspar (Figure 3B). The latter is suggestive of phyllic alteration developed on earlier potassic alteration. Chlorite, epidote and calcite are closely associated and constitute propylitic alteration assemblages that may also include montmorillonite. Propylitic assemblages may also develop on earlier potassic assemblages (Figure 3C,D). All alteration and ore-bearing assemblages are susceptible to experiencing fracturing and non-hydrothermal brecciation (Figure 3E,F), thus favouring the emplacement of later associations in all the mineralised areas in the Huanuni district. 

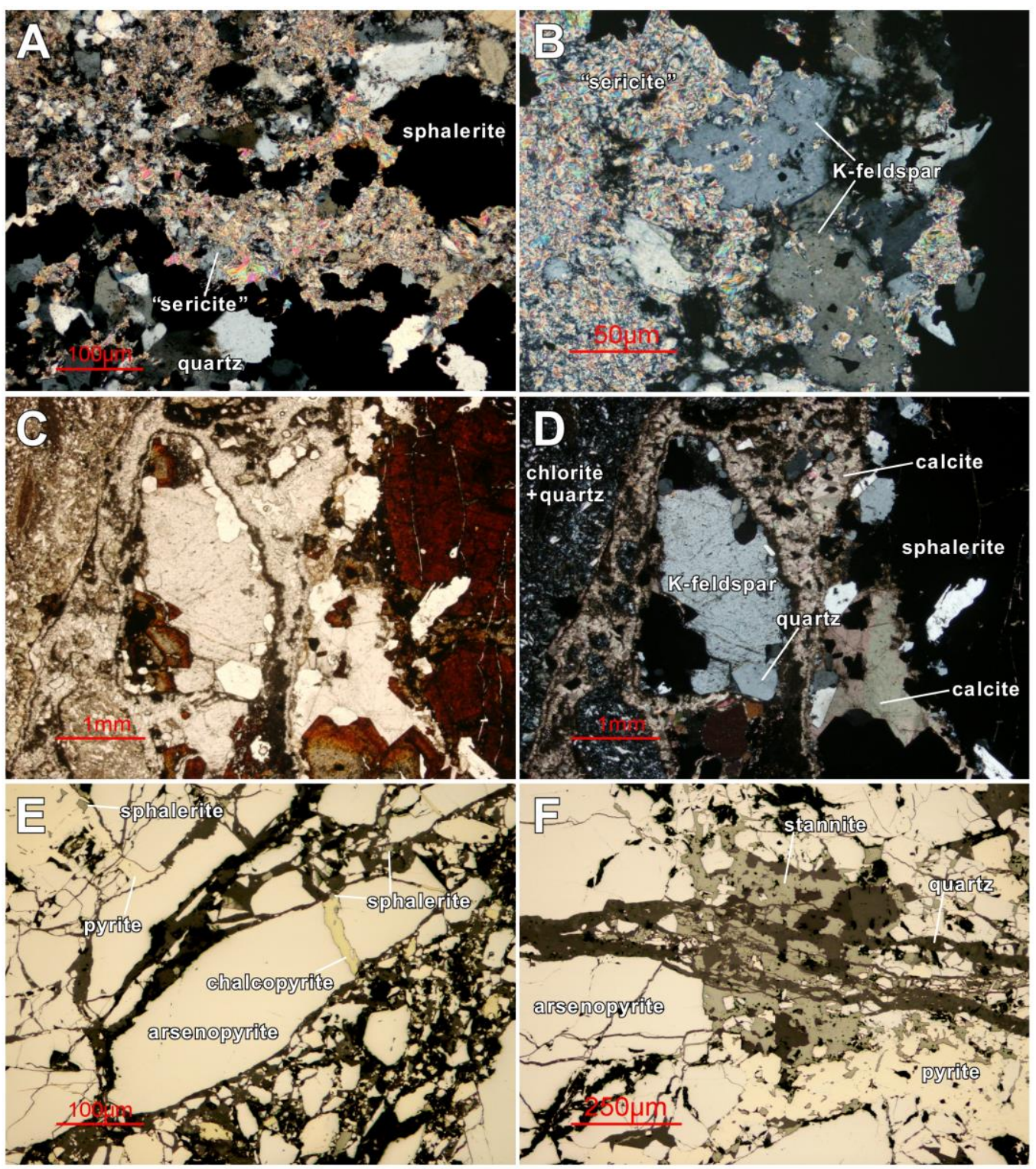

Figure 3. Photomicrographs of alteration minerals and microfracturing in the Huanuni deposit. (A) Pervasive phyllic alteration associated with sphalerite in the La Suerte area; transmitted polarised light, crossed polars (XPL). (B) Hydrothermal potassium feldspar (potassic alteration) replaced by pervasive phyllic alteration minerals in the La Suerte area; XPL. (C) Hydrothermal potassium feldspar (potassic alteration) associated with sphalerite, brecciated and postdated by propylitic alteration minerals in the Bonanza area; transmitted plane polarised light (TPPL). (D) Same as (C), XPL. (E) Two sets of microfracturing, the first one affecting stage- 1 pyrite and associated with stage- 2 chalcopyrite, and the second one within stage 2, in the Central area; reflected polarised light (RPPL). (F) Microfracturing that affects stage-2 stannite and earlier arsenopyrite and pyrite in the Central area; R PPL.

\subsection{Ore Minerals}

Besides the silicates mentioned above, the minerals that constitute hypogene ore associations in the deposit are dominantly sulphides and sulphosalts, oxides, wolframates, phosphates, and carbonates (Figures 4-6). These are consigned in alphabetical order for each of the groups above. Sulphides are acanthite $\left[\mathrm{Ag}_{2} \mathrm{~S}\right]$, arsenopyrite [FeAsS], bismuthinite $\left[\mathrm{Bi}_{2} \mathrm{~S}_{3}\right]$, černýite $\left[\mathrm{Cu}_{2} \mathrm{CdSnS} \mathrm{S}_{4}\right]$, chalcopyrite $\left[\mathrm{CuFeS}_{2}\right]$, cobaltite [CoAsS], galena [PbS], gersdorffite [NiAsS], marcasite [FeS], pyrite $\left[\mathrm{FeS}_{2}\right]$, pyrrhotite $\left[\mathrm{Fe}_{1-x} \mathrm{~S}\right]$, rhodostannite $\left[\mathrm{Cu}_{2} \mathrm{FeSn}_{3} \mathrm{~S}_{8}\right]$, sphalerite and wurtzite [ZnS], stannite-kësterite 
$\left[\mathrm{Cu}_{2} \mathrm{FeSnS}_{4}-\mathrm{Cu}_{2} \mathrm{ZnSnS}_{4}\right]$, and teallite $\left[\mathrm{PbSnS}_{2}\right]$. Sulphosalts are cervelleite $\left[\mathrm{Ag}_{4} \mathrm{TeS}\right]$, freibergite $\left[\mathrm{Ag}_{6}\left(\mathrm{Cu}_{4} \mathrm{Fe}_{2}\right) \mathrm{Sb}_{4} \mathrm{~S}_{13-x}\right]$, matildite $\left[\mathrm{AgBiS}_{2}\right]$, proustite-pyrargyrite $\left[\mathrm{Ag}_{3} \mathrm{AsS}_{3}-\mathrm{Ag}_{3} \mathrm{SbS}_{3}\right]$ and treasurite $\left[\mathrm{Ag}_{7} \mathrm{~Pb}_{6} \mathrm{Bi}_{15} \mathrm{~S}_{32}\right]$. Oxides are cassiterite $\left[\mathrm{SnO}_{2}\right]$, hematite $\left[\mathrm{Fe}_{2} \mathrm{O}_{3}\right]$, and rutile $\left[\mathrm{TiO}_{2}\right]$. Wolframates are the endmembers of wolframite, ferberite $\left[\mathrm{FeWO}_{4}\right]$ and hübnerite $\left[\mathrm{MnWO}_{4}\right]$. Phosphates are fluorapatite $\left[\mathrm{Ca}_{5}\left(\mathrm{PO}_{4}\right)_{3} \mathrm{~F}\right]$, and monazite- $(\mathrm{Ce})\left[(\mathrm{Ce}, \mathrm{La}, \mathrm{Nd}, \mathrm{Th}) \mathrm{PO}_{4}\right]$. Carbonates are calcite $\left[\mathrm{CaCO}_{3}\right]$, siderite $[\mathrm{FeCO} 3]$, and otavite $\left[\mathrm{CdCO}_{3}\right]$. There is also fluorite $\left[\mathrm{CaF}_{2}\right]$, native bismuth $[\mathrm{Bi}]$, and stetindite $\left[\mathrm{Ce}^{4+} \mathrm{SiO}_{4}\right], \mathrm{a}$ considerably rare mineral.

Other minerals, reported in earlier publications $[39,40]$ are boulangerite $\left[\mathrm{Pb}_{5} \mathrm{Sb}_{4} \mathrm{~S}_{11}\right]$, bournonite [ $\left.\mathrm{PbCuSbS}_{3}\right]$, cylindrite $\left[\mathrm{Pb}_{3} \mathrm{Sn}_{4} \mathrm{FeSb}_{2} \mathrm{~S}_{14}\right]$, franckeite $\left[\left(\mathrm{Pb}, \mathrm{Sn}_{6} \mathrm{Fe}^{2+} \mathrm{Sn}_{2} \mathrm{Sb}_{2} \mathrm{~S}_{14}\right]\right.$, freieslebenite [AgPbSbS 3$]$, greenockite [CdS], herzenbergite [SnS], jamesonite $\left[\mathrm{Pb}_{4} \mathrm{FeSb}_{6} \mathrm{~S}_{14}\right]$, owyheeite $\left[\mathrm{Pb}_{7} \mathrm{Ag}_{2}(\mathrm{Sb}, \mathrm{Bi})_{8} \mathrm{~S}_{20}\right]$, pavonite $\left[(\mathrm{Ag}, \mathrm{Cu})(\mathrm{Bi}, \mathrm{Pb})_{3} \mathrm{~S}_{5}\right]$, plagionite $\left[\mathrm{Pb}_{5} \mathrm{Sb}_{8} \mathrm{~S}_{17}\right]$, semseyite $\left[\mathrm{Pb}_{9} \mathrm{Sb}_{8} \mathrm{~S}_{21}\right]$, and stibnite $\left[\mathrm{Sb}_{2} \mathrm{~S}_{3}\right]$.

Supergene associations comprise a broad number of phosphates, sulphates, silicates, and carbonates. Sulphates are anglesite $\left[\mathrm{PbSO}_{4}\right]$, and szomolnokite $\left[\mathrm{FeSO}_{4} \cdot \mathrm{H}_{2} \mathrm{O}\right]$. Phosphates are drugmanite $\left[\mathrm{Pb}_{2}\left(\mathrm{Fe}^{3+}, \mathrm{Al}\right) \mathrm{H}\left(\mathrm{PO}_{4}\right)_{2}(\mathrm{OH})_{2}\right]$, plumbogummite $\left[\mathrm{PbAl}_{3}\left(\mathrm{PO}_{4}\right)_{2}(\mathrm{OH})_{5} \cdot \mathrm{H}_{2} \mathrm{O}\right]$, and pyromorphite $\left[\mathrm{Pb}_{5}\left(\mathrm{PO}_{4}\right)_{3} \mathrm{Cl}\right]$. The sole carbonate found as a supergene mineral in this study is an indium carbonate with no known stoichiometric formula, and that may constitute a new mineral species. Other supergene minerals, reported in earlier publications $[39,40]$ are aheylite $\left[\left(\mathrm{Fe}^{2+}, \mathrm{Zn}\right) \mathrm{Al}_{6}\left(\mathrm{PO}_{4}\right)_{4}(\mathrm{OH})_{8} \cdot 4 \mathrm{H}_{2} \mathrm{O}\right]$, chalcanthite $\left[\mathrm{CuSO}_{4} \cdot 5 \mathrm{H}_{2} \mathrm{O}\right]$, chalcosiderite $\left[\mathrm{CuFe}^{3+}{ }_{6}\left(\mathrm{PO}_{4}\right)_{4}(\mathrm{OH})_{8} \cdot 4 \mathrm{H}_{2} \mathrm{O}\right]$, crandallite $\left[\mathrm{CaAl}_{3}\left(\mathrm{PO}_{4}\right)_{2}(\mathrm{OH})_{5} \cdot \mathrm{H}_{2} \mathrm{O}\right]$, cronstedtite $\left[\mathrm{Fe}^{2+}{ }_{2} \mathrm{Fe}^{3+}\left(\mathrm{SiFe}^{3+}\right) \mathrm{O}_{5}(\mathrm{OH})_{4}\right]$, faustite $\left[(\mathrm{Zn}, \mathrm{Cu}) \mathrm{Al}_{6}\left(\mathrm{PO}_{4}\right)_{4}(\mathrm{OH})_{8} \cdot 4 \mathrm{H}_{2} \mathrm{O}\right]$, fibroferrite $\left[\mathrm{Fe}^{3+}\left(\mathrm{SO}_{4}\right)(\mathrm{OH}) \cdot 5 \mathrm{H}_{2} \mathrm{O}\right]$, hisingerite $\left[\mathrm{Fe}^{3+}{ }_{2} \mathrm{Si}_{2} \mathrm{O}_{5}(\mathrm{OH})_{4} \cdot 2 \mathrm{H}_{2} \mathrm{O}\right]$, hydrowoodwardite $\left[\mathrm{Cu}_{0.5} \mathrm{Al}_{0.5}(\mathrm{OH})_{2}\left(\mathrm{SO}_{4}\right)_{0.25} \cdot 0.75 \mathrm{H}_{2} \mathrm{O}\right]$, hydrozincite $\left[\mathrm{Zn}_{5}\left(\mathrm{CO}_{3}\right)_{2}(\mathrm{OH})_{6}\right]$, jarosite $\left[\mathrm{KFe}^{3+}{ }_{3}\left(\mathrm{SO}_{4}\right)_{2}(\mathrm{OH})_{6}\right]$, linarite $\left[\mathrm{PbCu}\left(\mathrm{SO}_{4}\right)(\mathrm{OH})_{2}\right]$, ludlamite $\left[\left(\mathrm{Fe}^{2+}, \mathrm{Mg}, \mathrm{Mn}\right)_{3}\left(\mathrm{PO}_{4}\right)_{2} \cdot 4 \mathrm{H}_{2} \mathrm{O}\right]$, montetrisaite $\left[\mathrm{Cu}_{6}\left(\mathrm{SO}_{4}\right)(\mathrm{OH})_{10} \cdot \mathrm{H}_{2} \mathrm{O}\right]$, nikischerite $\left[\mathrm{NaFe}^{2+}{ }_{6} \mathrm{Al}_{3}\left(\mathrm{SO}_{4}\right)_{2}(\mathrm{OH})_{18} \cdot 12 \mathrm{H}_{2} \mathrm{O}\right]$, perhamite $\left[\mathrm{Ca}_{3} \mathrm{Al}_{7}\left(\mathrm{SiO}_{4}\right)_{3}\left(\mathrm{PO}_{4}\right)_{4}(\mathrm{OH})_{3} \cdot 16.5 \mathrm{H}_{2} \mathrm{O}\right]$, redgillite $\left[\mathrm{Cu}_{6}(\mathrm{OH})_{10}\left(\mathrm{SO}_{4}\right) \cdot \mathrm{H}_{2} \mathrm{O}\right]$, scorodite $\left[\mathrm{Fe}^{3+}\left(\mathrm{AsO}_{4}\right) \cdot 2 \mathrm{H}_{2} \mathrm{O}\right]$, valentinite $\left[\mathrm{Sb}_{2} \mathrm{O}_{3}\right]$, variscite $\left[\mathrm{AlPO}_{4} \cdot 2 \mathrm{H}_{2} \mathrm{O}\right.$, vivianite $\left[\mathrm{Fe}^{2+}{ }_{3}\left(\mathrm{PO}_{4}\right)_{2} \cdot 8 \mathrm{H}_{2} \mathrm{O}\right]$, and wavellite $\left[\mathrm{Al}_{3}\left(\mathrm{PO}_{4}\right)_{2}(\mathrm{OH}, \mathrm{F})_{3} \cdot 5 \mathrm{H}_{2} \mathrm{O}\right]$.

\subsection{Petrography}

Pyrite is one of the most abundant metallic minerals in either mineralised area of this deposit and its aggregates may form several types of textures (Figure 4), including "bird's eyes" along with marcasite or other textures that resulted from pyrrhotite replacement through an increase in sulphidation. However, pyrite can be replaced by sphalerite (Figure 4A), arsenopyrite or hematite.

Pyrrhotite is an abundant mineral in the Central area but nearly absent in the peripheral areas of the deposit. Besides being commonly replaced by pyrite and by fine intergrowths of pyrite-marcasite (intermediate product), it can be replaced by stannite, galena and sphalerite.

Arsenopyrite is a major metallic mineral in the Central and La Suerte areas, although it is relatively scarce in the Bonanza area. It generally occurs as euhedral and subhedral crystals partially replaced by chalcopyrite or pyrrhotite through microfractures.

Sphalerite is observed interstitial to arsenopyrite crystals (Figure 4B) pointing to a later crystallization. Sphalerite also occurs after pyrite, either reactively (Figure 4A,D) or passively (Figure 4C). Sphalerite, chalcopyrite and galena are conspicuous minerals in the Bonanza and La Suerte areas, although they are relatively scarce in the Central area. Chalcopyrite occurs generally replacing sphalerite as chalcopyrite disease textures (Figure 4A) or in microfractures (Figure 3E).

Sphalerite can be also replaced by galena and late sulphosalts, and may also present exsolutions of rare černýite (Figure 4B). Sphalerite is one of the main indium-bearing minerals in the deposit, as attested by an unidentified indium carbonate that forms in close association with sphalerite as its supergene alteration product (Figure $6 \mathrm{~F}$ ). Besides sphalerite, galena may also replace pyrite and hematite and, in turn, it is replaced by late sulphosalts.

$\mathrm{Zn}$ - and Sn-rich assemblages are often spatially associated with apatite (Figure 4D) and potassium feldspar (Figure 4F), at least in the Central area, which suggests that such assemblages are associated 
with potassic assemblages. Rutile is a characteristic mineral of the peripheral areas of the mineralisation, replaced by quartz and wurtzite (Figure 4E).
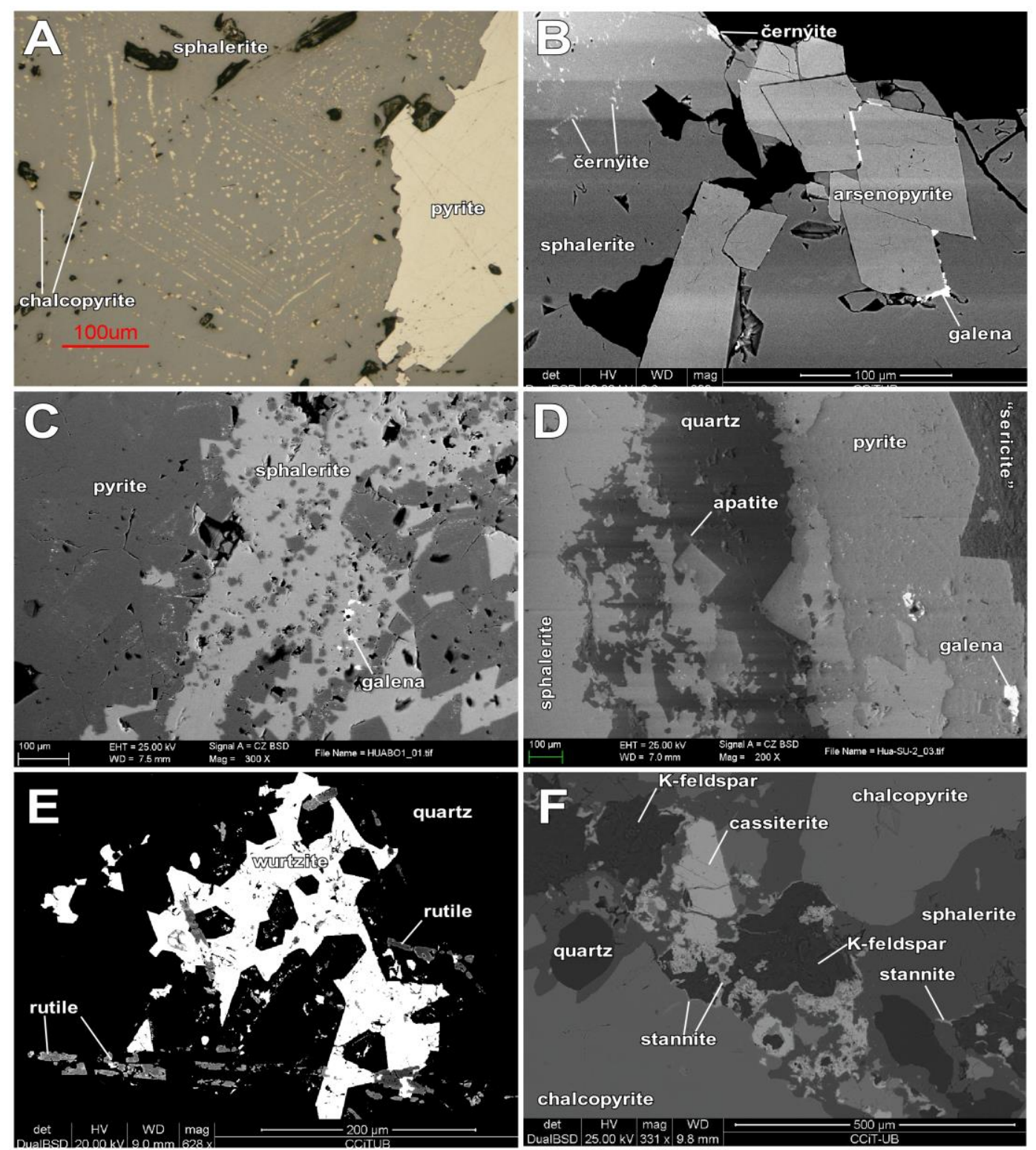

Figure 4. Photomicrographs of Zn-rich base metal associations in the Huanuni deposit. (A) Chalcopyrite disease textures in sphalerite that replace earlier pyrite in the Bonanza area; RPPL. (B) Stage-2 base metal sulphides with exsolved černýite from sphalerite in the La Suerte area; back-scattered electron (BSE) image. (C) Stage-2 base metal sulphides in the Bonanza area; notice the passive precipitation of sphalerite after pyrite; BSE image. (D) Stage-2 base metal sulphides in association with phyllic-alteration minerals in the La Suerte area; notice the reactive precipitation of sphalerite after pyrite and the occurrence of apatite; BSE image. (E) Stage-2 rutile associated with quartz and wurtzite in the La Suerte area; BSE image. (F) Stage-2 base metal-rich association with sphalerite partly replaced by chalcopyrite, cassiterite, and stage- 3 stannite rimming potassium feldspar (potassic assemblage) in the Central area; BSE image. 


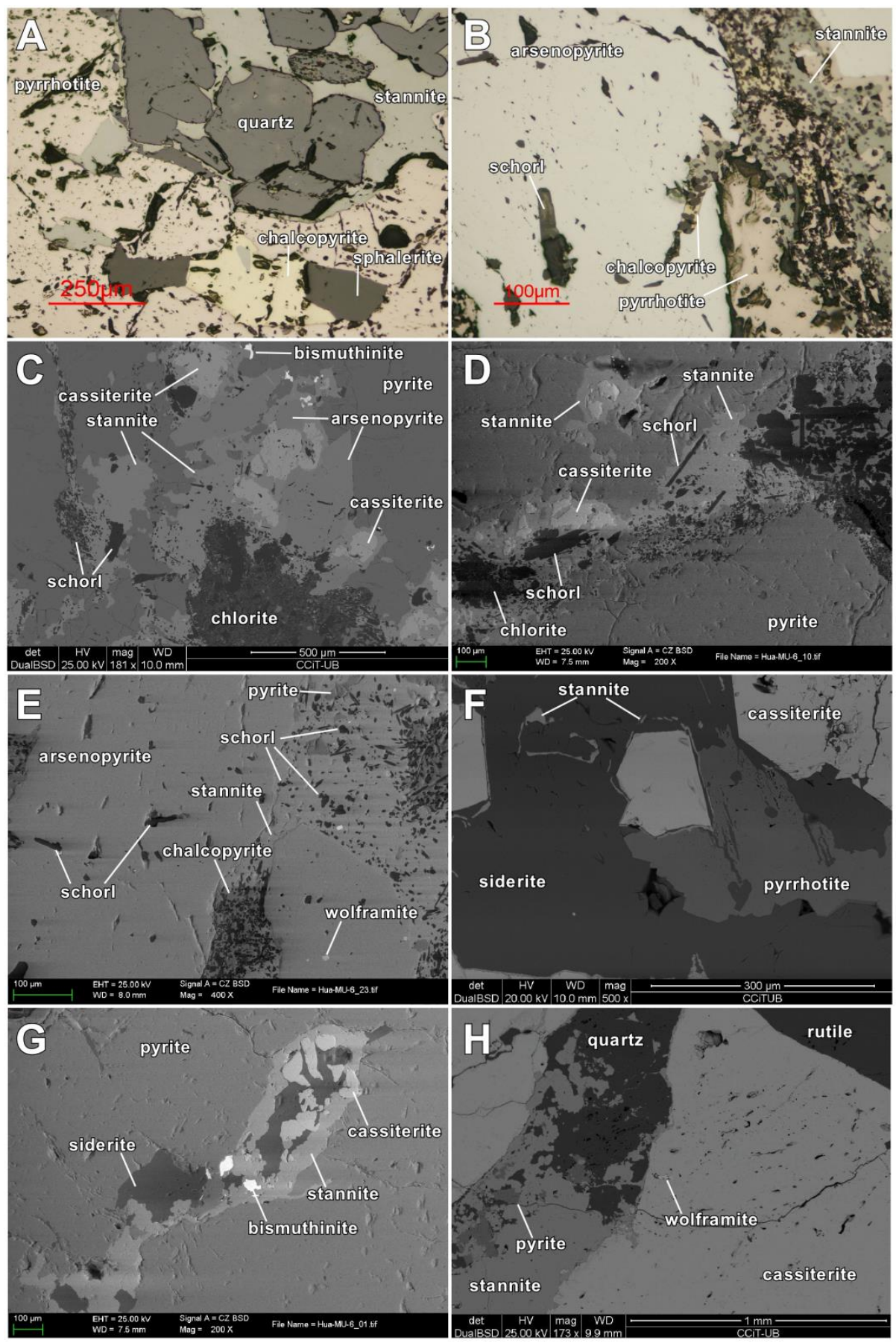

Figure 5. Photomicrographs of tin-rich associations in the Huanuni deposit. (A) Stage-2 chalcopyrite and sphalerite, and stage- 3 stannite and chalcopyrite replacing stage- 1 pyrrhotite and quartz in the Central area; RPPL. (B) Stage-1 arsenopyrite replaced by stage- 2 pyrrhotite, schorl and chalcopyrite, then by stage-3 stannite in the Central area; RPPL. (C-E) Similar sequence to that in B including stage- 1 pyrite and cassiterite, stage- 2 chlorite (chamosite) and stage- 3 bismuthinite in the Central area; back-scattered electron (BSE) images. (F) Stage-2 association between siderite and cassiterite replacing earlier pyrrhotite, and cassiterite being replaced by stage-3 stannite in the Central area; BSE image. (G) Stage-2 cassiterite and siderite, and stage-3 stannite and bismuthinite replacing earlier pyrite in the Central area; BSE image. (H) Stage-2 wolframite and cassiterite crosscut and replaced by stage-3 stannite, quartz and pyrite in the La Suerte area; BSE image. 

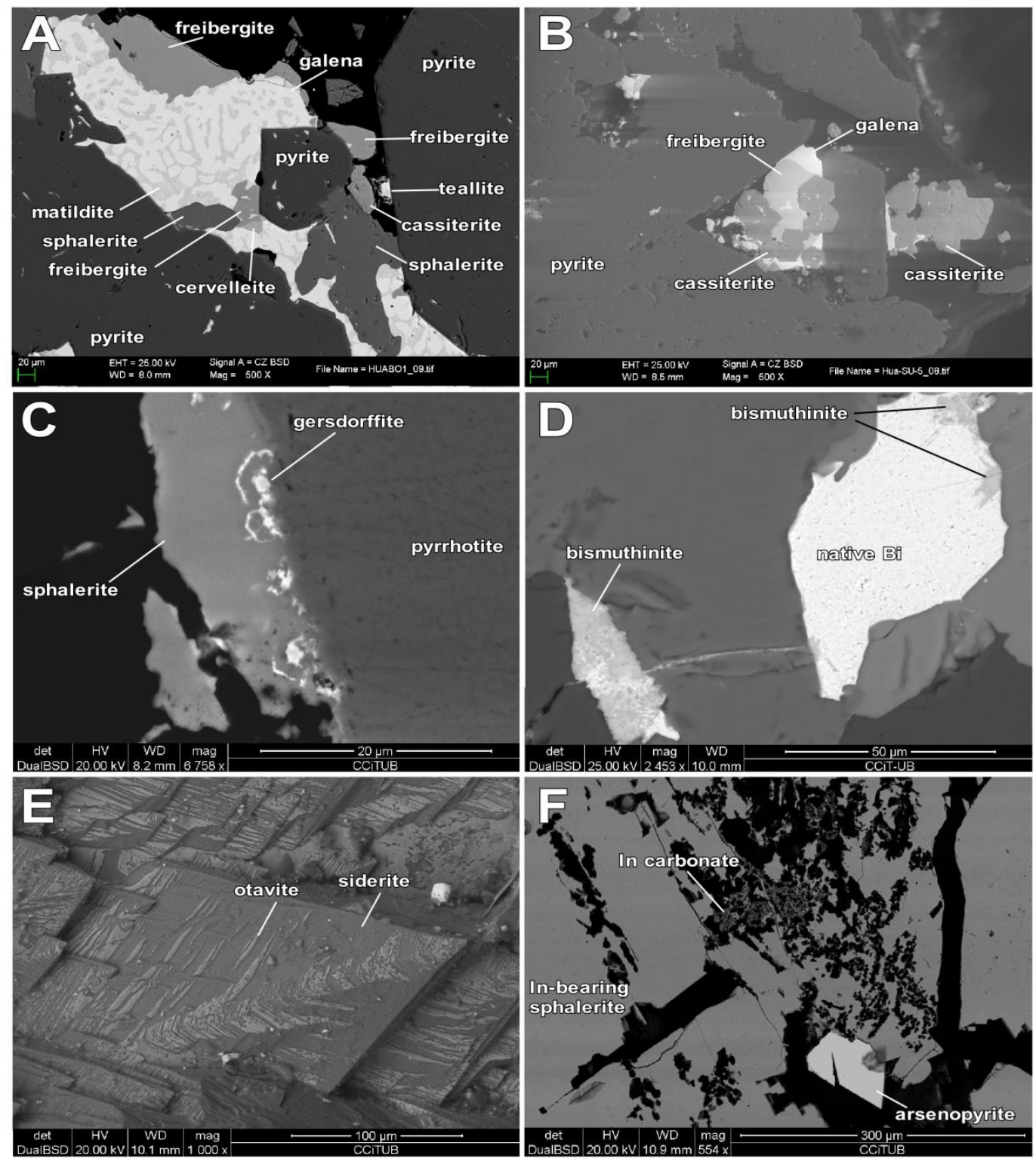

Figure 6. Photomicrographs of late mineral associations and rare minerals in the Huanuni deposit. (A,B) Silver-rich association of stage 3 in the Bonanza area; notice freibergite, matildite and cervelleite replacing galena but not cassiterite. (C) Stage-1 pyrrhotite replaced by stage- 2 sphalerite and rare gersdorffite in the Central area. (D) Stage- 2 native bismuth replaced by stage-3 bismuthinite in the Central area. (E) Stage-2 siderite intergrown with otavite in the Central area. (F) Stage-2 indium-bearing sphalerite replaced by a supergene unknown indium carbonate species in the Bonanza area. All are back-scattered electron (BSE) images.

Cassiterite and stannite are the most abundant Sn minerals in the deposit (Figure 5). Cassiterite is relatively abundant in the Central area, generally as passively precipitated vein material along with quartz and pyrrhotite or arsenopyrite (hence, an early mineral (Figure 5C,F,H)) as euhedral to subhedral crystals or, less frequently, in association with pyrite or stannite (Figure 5C,D,G). It is commonly replaced by stannite (with or without schorl (Figure 5B-D,F-H)). Cassiterite is relatively scarce in peripheral areas of the deposit, where it systematically postdates early $\mathrm{Zn}$-rich associations as anhedral crystals replaced, in turn, by later sulphides and sulphosalts. Siderite is also common in the Central area, in association with cassiterite (Figure 5F,G), intergrown with rare otavite (Figure 6E), due to the alteration of pyrrhotite, and is a scarce mineral in the peripheral zones of the deposit. 
Stannite-kësterite is a common mineral in the Central area of the deposit, normally as replacements after pre-existing sulphides (Figures $4 \mathrm{~F}$ and 5), and can be found in close association with schorl (Figure 5B-E) and "sericite". It was also found in the La Suerte area.

Sn-rich assemblages in the Huanuni deposit are systematically postdated by Ag-rich assemblages (Figure 6A,B). The latter are associated with "sericite" both in the Central and peripheral zones. Freibergite is possibly the most abundant silver mineral in the deposit and is common in the Bonanza area, in close association with matildite, galena, cervelleite and teallite (Figure 6A,B). Galena forms symplectitic textures along with matildite and/or proustite-pyrargyrite in the latest hypogene assemblages of the deposit (Figure 6A).

Acanthite, argentopyrite, apatite, bismuthinite, cervelleite, cobaltite, ferberite and hübnerite (wolframite), gersdorffite, monazite-(Ce), rhodostannite, rutile, treasurite, wurtzite and stetindite are scarce minerals. Despite their scarcity and the inherent difficulty in determining their occurrence or abundance, nickel, cobalt and tungsten minerals (gersdorffite, cobaltite and wolframite) are seemingly confined to the Central area of the deposit. Cobaltite and gersdorffite occur in association with sphalerite (Figure 6C). Bismuthinite occurs late in the hypogene assemblages as replacements of earlier native bismuth (Figure 6D).

\subsection{Paragenetic Sequences}

All mineralised areas recorded paragenetic sequences that can be simplified into three hypogene stages of mineralisation, and correlated among the three mineralised areas despite their differences in mineralogy (Figures 7 and 8). Stage 1 consists of base-metal sulphides and may contain cassiterite and acanthite. Stage 2 is also base metal-rich and is the main carrier of schorl, cassiterite and indium-bearing sphalerite in the deposit; the occurrences of cobalt, nickel and cerium minerals belong to this stage as well. Stage 3 consists of sulphosalt-rich associations and is the main carrier of silver minerals, particularly in the peripheral areas of the deposit. Supergene associations are dominated by phosphates, sulphates, oxihydroxides, arsenates, carbonates, etc., particularly with iron, copper, and lead as major cations (e.g., drugmanite).

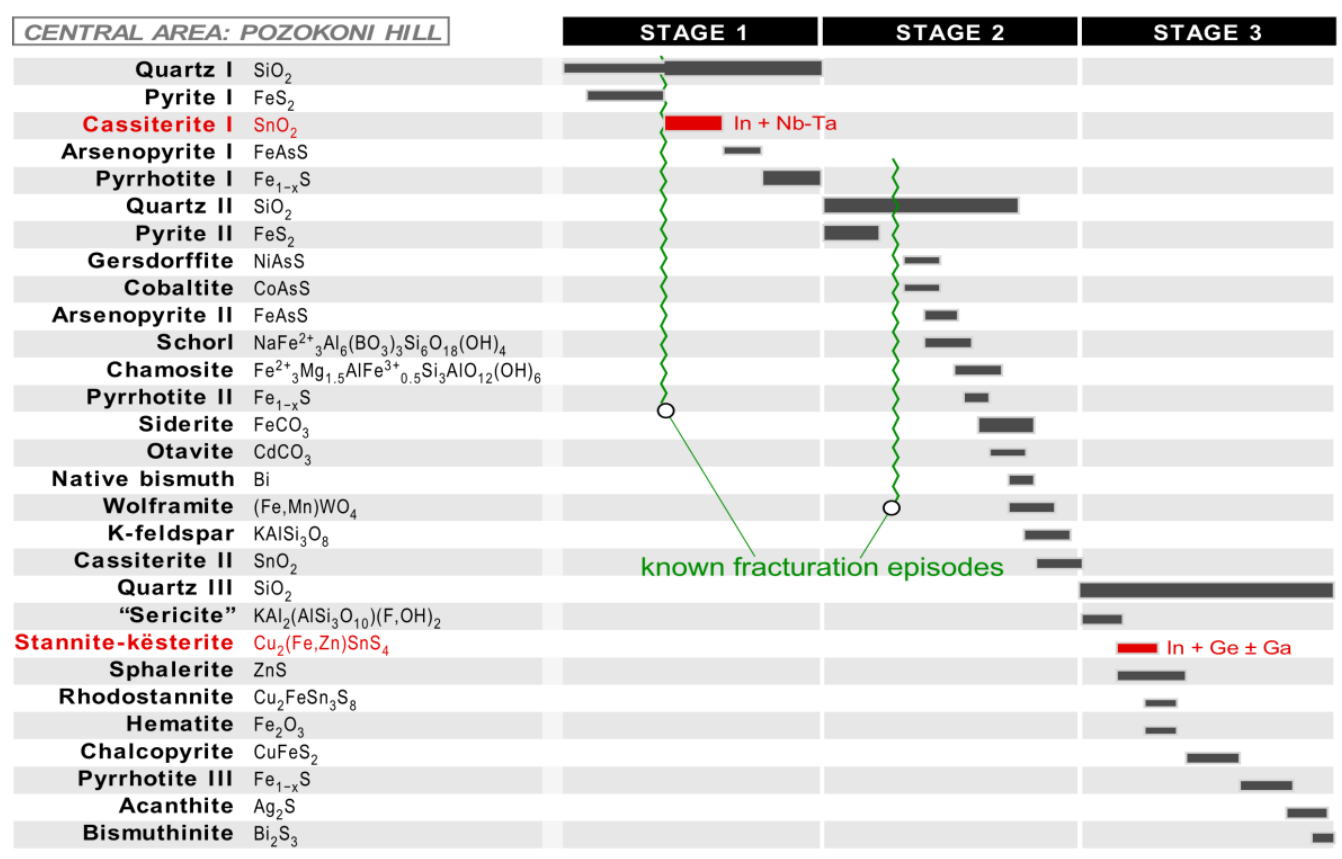

Figure 7. Paragenetic sequence in the Central area of the Huanuni deposits, or Pozokoni Hill area. Minerals highlighted in red are those with significant concentrations in $\mathrm{In}, \mathrm{Ge}, \mathrm{Ga}, \mathrm{Nb}$ and $\mathrm{Ta}$. 

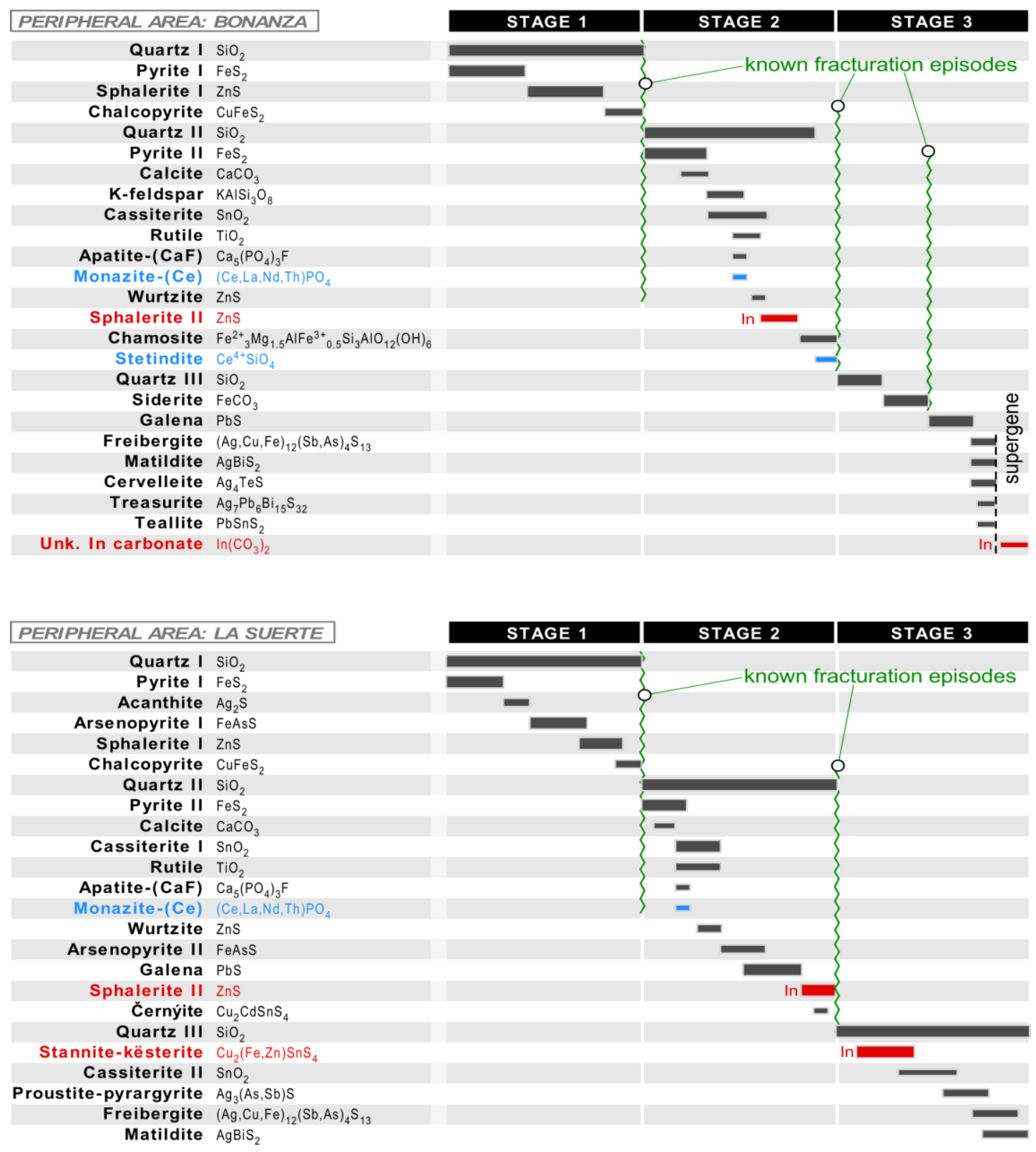

Figure 8. The paragenetic sequence in the peripheral areas of the Huanuni deposits (Bonanza and La Suerte areas). Minerals highlighted in red are those with significant concentrations in In, Ge and Ga, and Ce-bearing minerals in blue.

Drusy quartz occurs in all stages in the three mineralised areas. Stage 1 in the Central area (Figure 7) is characterised by open-space lining with quartz, cassiterite, arsenopyrite (essentially euhedral) and pyrrhotite (as groundmasses). During stage 2 in the Central area, pyrite and arsenopyrite were deposited in association with gersdorffite and cobaltite. These minerals were followed by a sub-stage with schorl, chamosite and siderite, and then by native bismuth, wolframite and the second generation of cassiterite, locally crystallizing as the needle tin variety. Stage 3 in the Central area is characterized by the precipitation of stannite, sphalerite (with chalcopyrite disease textures), and the third generation of pyrrhotite lining micro-fractures; the final association consists of "sericite", acanthite and bismuthinite, frequently replacing native bismuth.

Stage 1 in the La Suerte peripheral area (Figure 8) consists of the first generation of pyrite and acanthite, followed by the crystallisation of euhedral arsenopyrite and sphalerite with chalcopyrite 
disease textures. Stage 2 in the La Suerte peripheral area consists of the second generation of pyrite, rutile and a first generation of cassiterite, followed by a second generation of arsenopyrite that partly replaced pyrite, galena, "sericite", and sphalerite. Stage 3 in the La Suerte peripheral area consists of stannite-kësterite and the second generation of cassiterite, followed by silver sulphosalts such as matildite, freibergite and proustite-pyrargyrite.

\section{Mineral Chemistry}

Sphalerite from the three mineralised areas was analysed by means of EPMA. Its maximum iron contents occur in the Central area: up to $11 \mathrm{wt} . \% \mathrm{Fe}$ (average $6.62 \mathrm{wt} . \% \mathrm{Fe}$ ) in the Bonanza area, up to $11.97 \mathrm{wt} . \% \mathrm{Fe}$ (average $9.26 \mathrm{wt} . \% \mathrm{Fe}$ ) in the La Suerte area, and up to $21.8 \mathrm{wt} . \% \mathrm{Fe}$ (average $9.5 \mathrm{wt} . \%$ $\mathrm{Fe}$ ) in the Central area (Table 1 and Table S1). Most indium contents in sphalerite (Figure 9, Table 1 and Table S1) are below the detection limit, but some grains are up to $0.88 \mathrm{wt} . \%$ In (average $0.24 \mathrm{wt} . \% \mathrm{In}$ ) in the Central area, up to $0.82 \mathrm{wt} . \%$ In (average $0.2 \mathrm{wt} . \%$ In) in the Bonanza area, and up to $0.17 \mathrm{wt} . \% \mathrm{In}$ (average $0.02 \mathrm{wt} . \%$ In) in the La Suerte area. Therefore, the highest indium concentrations occur in stage- 2 sphalerite in the Central and Bonanza areas. Cadmium contents in sphalerite are up to $0.7 \mathrm{wt} . \%$ $\mathrm{Cd}$ in the Central area but attain the highest average values in the Bonanza area $(0.43 \mathrm{wt} . \% \mathrm{Cd})$.

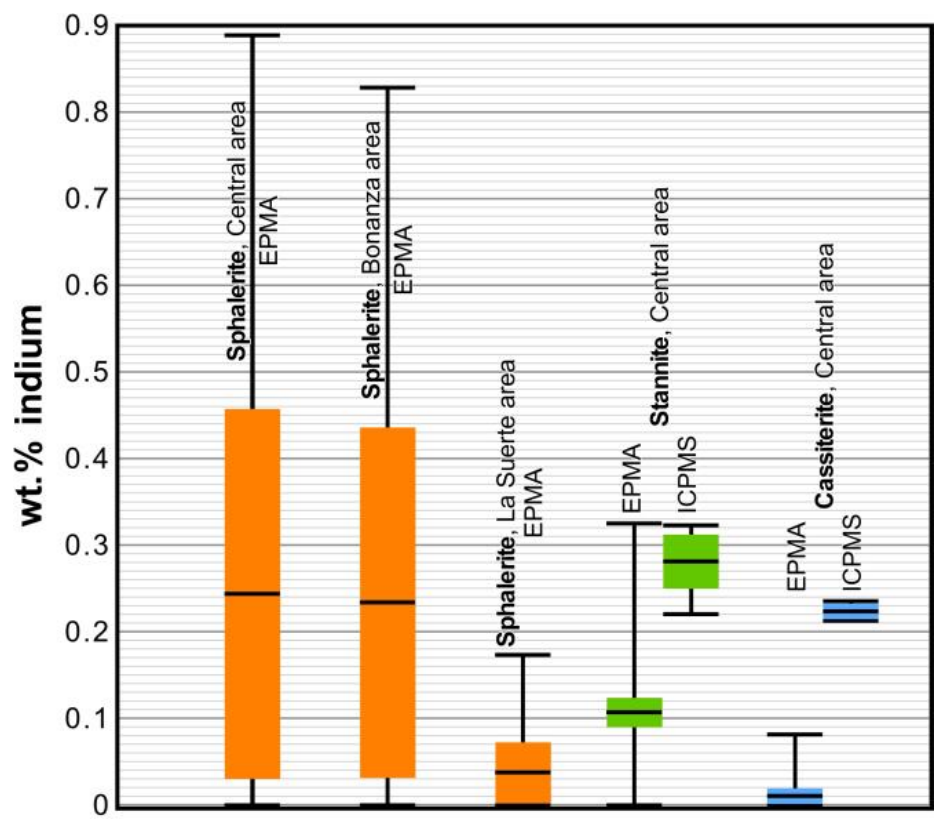

Figure 9. Indium concentrations in sphalerite (orange), stannite (green) and cassiterite (blue), by means of EPMA and LA-ICP-MS. Boxes represent the span of standard deviations, with an indication of average values (horizontal line), and black lines represent the span of the total variation of analytical values.

As of EPMA analyses (Table S1), in the cassiterite samples from the Central area were recorded (by means of EPMA) concentrations up to $1.42 \mathrm{wt} . \% \mathrm{TiO}_{2}$ (average $0.15 \mathrm{wt} . \% \mathrm{TiO}_{2}$ ), up to $1.21 \mathrm{wt} . \%$ $\mathrm{FeO}$ (average 0.66 wt. $\%$ ), up to 0.37 wt. $\% \mathrm{Ta}_{2} \mathrm{O}_{5}$ (average 0.05 wt. $\% \mathrm{Ta}_{2} \mathrm{O}_{5}$ ), and up to $0.23 \mathrm{wt} . \% \mathrm{Nb}_{2} \mathrm{O}_{5}$ (average $0.04 \mathrm{wt} . \% \mathrm{Nb}_{2} \mathrm{O}_{5}$ ), although its $\mathrm{Nb}$ and Ta contents are mostly below the detection limits for these elements. Indium occurs below its detection limit in most of the cassiterite analyses. LA-ICP-MS analyses in cassiterite (Figures 9 and 10, Table S2) also yielded low values in critical elements, clustering around 0.2 wt. $\% \operatorname{In}_{2} \mathrm{O}_{3}$ ). 
Table 1. Summary of compositions of significant elements in key minerals of the Huanuni deposits (see full dataset in Tables S1 and S2).

\begin{tabular}{|c|c|c|c|c|c|c|}
\hline Mineral & Area & Element & Type of Value & wt. $\%$ & $n$ & Method \\
\hline \multirow{32}{*}{ sphalerite } & \multirow{8}{*}{ Central } & \multirow[t]{4}{*}{$\mathrm{Fe}$} & Average & 9.50 & \multirow[t]{4}{*}{23} & \multirow[t]{4}{*}{ EPMA } \\
\hline & & & Std.dev. & 5.43 & & \\
\hline & & & Maximum & 21.80 & & \\
\hline & & & Minimum & 0.27 & & \\
\hline & & \multirow[t]{4}{*}{ In } & Average & 0.24 & \multirow[t]{4}{*}{23} & \multirow[t]{4}{*}{ EPMA } \\
\hline & & & Std.dev. & 0.21 & & \\
\hline & & & Maximum & 0.88 & & \\
\hline & & & Minimum & b.d.l. & & \\
\hline & \multirow{8}{*}{ Bonanza } & \multirow[t]{4}{*}{$\mathrm{Fe}$} & Average & 6.62 & \multirow[t]{4}{*}{11} & \multirow[t]{4}{*}{ EPMA } \\
\hline & & & Std.dev. & 4.04 & & \\
\hline & & & Maximum & 11.00 & & \\
\hline & & & Minimum & 0.48 & & \\
\hline & & \multirow[t]{4}{*}{ In } & Average & 0.20 & \multirow[t]{4}{*}{11} & \multirow[t]{4}{*}{ EPMA } \\
\hline & & & Std.dev. & 0.23 & & \\
\hline & & & Maximum & 0.82 & & \\
\hline & & & Minimum & b.d.l. & & \\
\hline & \multirow{8}{*}{ La Suerte } & \multirow[t]{4}{*}{$\mathrm{Fe}$} & Average & 9.26 & \multirow[t]{4}{*}{19} & \multirow[t]{4}{*}{ EPMA } \\
\hline & & & Std.dev. & 2.67 & & \\
\hline & & & Maximum & 11.97 & & \\
\hline & & & Minimum & 2.86 & & \\
\hline & & \multirow[t]{4}{*}{ In } & Average & 0.02 & \multirow[t]{4}{*}{19} & EPMA \\
\hline & & & Std.dev. & 0.05 & & \\
\hline & & & Maximum & 0.17 & & \\
\hline & & & Minimum & b.d.l. & & \\
\hline & & $\mathrm{Fe}$ & Average & 8.82 & 53 & EPMA \\
\hline & & & Std.dev. & 4.40 & & \\
\hline & & & Maximum & 21.80 & & \\
\hline & & & Minimum & 0.27 & & \\
\hline & All areas & In & Average & 0.15 & 53 & EPMA \\
\hline & & & Std.dev. & 0.20 & & \\
\hline & & & Maximum & 0.88 & & \\
\hline & & & Minimum & b.d.l. & & \\
\hline & & In & Average & 0.12 & 19 & EPMA \\
\hline & & & Std.dev. & 0.09 & & \\
\hline & & & Maximum & 0.32 & & \\
\hline & & & Minimum & b.d.l. & & \\
\hline & & In & Average & 0.28 & 7 & LAICPMS \\
\hline & & & Std.dev. & 0.03 & & \\
\hline & & & Maximum & 0.33 & & \\
\hline stannite & Central & & Minimum & 0.23 & & \\
\hline stannite & Central & $\mathrm{Ge}$ & Average & - & 19 & EPMA \\
\hline & & & Std.dev. & - & & \\
\hline & & & Maximum & 0.13 & & \\
\hline & & & Minimum & b.d.l. & & \\
\hline & & $\mathrm{Ga}$ & Average & 63 ppm & 7 & LAICPMS \\
\hline & & & Std.dev. & 40 ppm & & \\
\hline & & & Maximum & 123 ppm & & \\
\hline & & & Minimum & 8 ppm & & \\
\hline
\end{tabular}


Table 1. Cont.

\begin{tabular}{|c|c|c|c|c|c|c|}
\hline Mineral & Area & Element & Type of Value & wt. $\%$ & $n$ & Method \\
\hline \multirow{16}{*}{ cassiterite } & \multirow{16}{*}{ Central } & \multirow{4}{*}{$\mathrm{In}_{2} \mathrm{O}_{3}$} & Average & 0.01 & \multirow[t]{4}{*}{50} & \multirow[t]{4}{*}{ EPMA } \\
\hline & & & Std.dev. & 0.01 & & \\
\hline & & & Maximum & 0.08 & & \\
\hline & & & Minimum & b.d.l. & & \\
\hline & & \multirow[t]{3}{*}{ In } & Average & 0.22 & \multirow[t]{4}{*}{3} & \multirow[t]{4}{*}{ LAICPMS } \\
\hline & & & Std.dev. & 0.01 & & \\
\hline & & & Maximum & 0.22 & & \\
\hline & & & Minimum & 0.21 & & \\
\hline & & \multirow[t]{4}{*}{$\mathrm{Nb}_{2} \mathrm{O}_{5}$} & Average & 0.04 & \multirow[t]{4}{*}{50} & \multirow[t]{4}{*}{ EPMA } \\
\hline & & & Std.dev. & 0.06 & & \\
\hline & & & Maximum & 0.21 & & \\
\hline & & & Minimum & b.d.l. & & \\
\hline & & \multirow[t]{4}{*}{$\mathrm{Ta}_{2} \mathrm{O}_{5}$} & Average & 0.05 & \multirow[t]{4}{*}{50} & \multirow[t]{4}{*}{ EPMA } \\
\hline & & & Std.dev. & 0.08 & & \\
\hline & & & Maximum & 0.37 & & \\
\hline & & & Minimum & b.d.l. & & \\
\hline
\end{tabular}

Key: b.d.l. = values below the detection limit, $n=$ number of analyses.

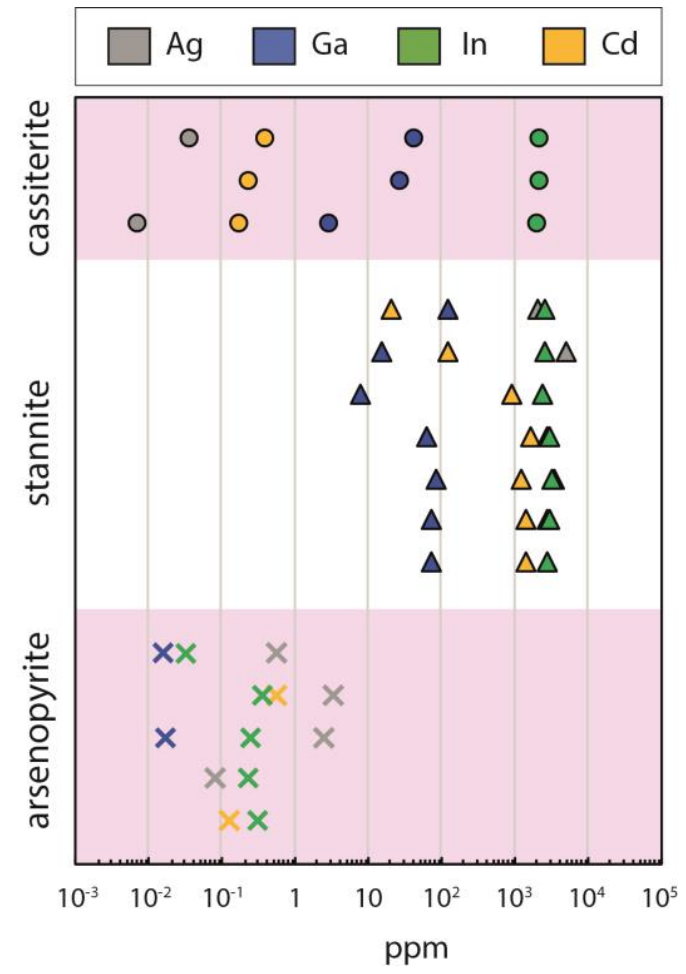

Figure 10. Trace and major element contents in stannite and cassiterite of the Huanuni deposit as per LA-ICP-MS determinations.

Stannite-kësterite from the Central area shows several elemental substitutions, ranging between 0.1 wt. $\%$ and 6.31 wt. $\% \mathrm{Zn}$, up to 0.29 wt.\% Ag, up to 0.13 wt. \% Ge, and up to 0.32 wt.\% In (average 0.12 wt.\% In; EPMA; Table S1). LA-ICP-MS analyses in stannite-kësterite (Figures 9 and 10, Table S2) yielded similar values to those obtained by EPMA (Table S2).

In summary, the specific analyses to determining the occurrence and contents in critical elements allow indicating that In is consistently present in stannite, cassiterite and, particularly, sphalerite. Ga yielded low contents in stannite, and other critical elements like $\mathrm{Nb}$ or Ta occur in low contents in cassiterite. 


\section{Sulphur Isotopes}

Sulphur isotope determinations were carried out on 30 sulphide (sphalerite, galena, pyrrhotite and pyrite) samples from the three mineralised areas of the Huanuni deposit (Table 2 and Figure 11). $\delta^{34} \mathrm{~S}$ values range between $-7.5 \%$ o and $-0.2 \%$ o in galena, between $-4.2 \%$ o and $0.2 \%$ o in sphalerite, between $-6.3 \%$ and $1.0 \%$ in pyrite, and between $-6.2 \%$ ond $-5.3 \%$ o in pyrrhotite. $\delta^{34} \mathrm{~S}$ values altogether are grouped around $0 \%$ in the peripheral Bonanza and La Suerte areas $(-4.2 \%$ o to $1.0 \%$ o) but skewed toward lower values in the Central area $(-7.2 \%$ o to $0.2 \%$ o). However, pyrite samples from the Central area yielded a broad variation in $\delta^{34} S$ values, ranging between $-6.3 \%$ ond $0.2 \%$ o. $\delta^{34} \mathrm{~S}$ values for the entire deposit range between $-7.5 \%$ and $1.0 \%$ altogether and describe a nearly bimodal distribution that can be narrowed down between $-7 \%$ ond $-5 \%$, and between $-2 \%$ ond $1 \%$; such data distribution corresponds to the majority of samples from the Central and peripheral areas, respectively.

Table 2. Sulphur isotope compositions of sulphides in the Huanuni deposit.

\begin{tabular}{|c|c|c|c|c|}
\hline Area & Mine & Sample & Mineral & $\delta^{34} S_{\text {VCDT }}(\%)$ \\
\hline \multirow{12}{*}{ Central } & \multirow{12}{*}{ Huanuni } & \multirow{2}{*}{ HUA-240 } & galena & -7.5 \\
\hline & & & pyrite & -2.0 \\
\hline & & HUA-240-1 & pyrrhotite & -5.8 \\
\hline & & HUA-240-2 & pyrrhotite & -5.9 \\
\hline & & HUA-MU-2 & $\begin{array}{c}\text { pyrite } \\
\text { pyrrhotite }\end{array}$ & $\begin{array}{c}0.2 \\
-5.3\end{array}$ \\
\hline & & HUA-MU-3 & pyrite & -6.3 \\
\hline & & HUA-MU-4 & pyrite & -4.5 \\
\hline & & HUA-MU-5 & pyrite & -5.3 \\
\hline & & \multirow{2}{*}{ HUA-MU-6 } & pyrite & -5.9 \\
\hline & & & pyrite & -6.1 \\
\hline & & HUA-MU-7 & pyrite & -0.1 \\
\hline & & HUA-MU-8 & pyrrhotite & -6.2 \\
\hline \multirow{10}{*}{ Peripheral } & \multirow{4}{*}{ Bonanza } & HUA-BO-1 & pyrite & -0.8 \\
\hline & & HUA-BO-2 & pyrite & 0.5 \\
\hline & & HUA-BO-3 & sphalerite & -1.1 \\
\hline & & HUA-BO-4 & pyrite & -1.3 \\
\hline & \multirow{6}{*}{ La Suerte } & HUA-SU-1 & $\begin{array}{l}\text { sphalerite } \\
\text { sphalerite }\end{array}$ & $\begin{array}{l}-4.2 \\
-1.7\end{array}$ \\
\hline & & HUA-SU-2 & $\begin{array}{c}\text { pyrite } \\
\text { sphalerite }\end{array}$ & $\begin{array}{c}-0.9 \\
0.2\end{array}$ \\
\hline & & HUA-SU-3 & $\begin{array}{c}\text { pyrite } \\
\text { pyrite } \\
\text { sphalerite } \\
\text { galena }\end{array}$ & $\begin{array}{c}-1.8 \\
1.0 \\
-1.0 \\
-0.2\end{array}$ \\
\hline & & HUA-SU-4 & $\begin{array}{l}\text { pyrite } \\
\text { galena }\end{array}$ & $\begin{array}{l}-1.3 \\
-1.7\end{array}$ \\
\hline & & HUA-SU-5 & pyrite & 0.8 \\
\hline & & HUA-SU-6 & $\begin{array}{c}\text { pyrite } \\
\text { sphalerite }\end{array}$ & $\begin{array}{c}0.5 \\
-3.3\end{array}$ \\
\hline
\end{tabular}




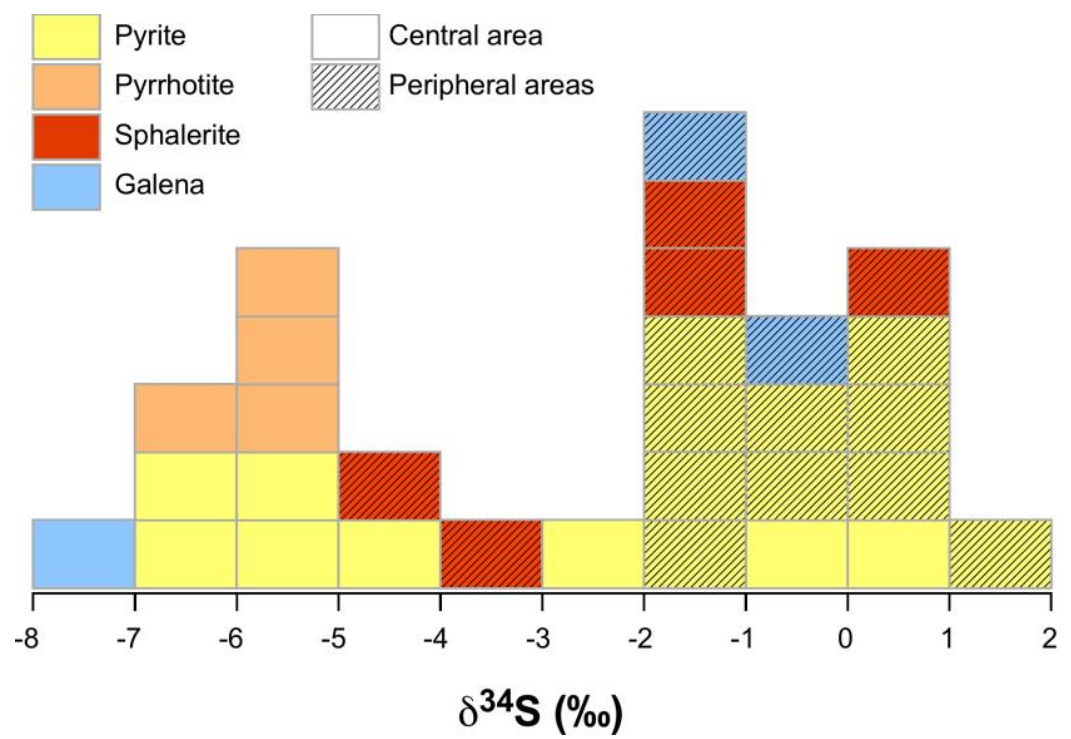

Figure 11. Histogram of sulphur isotopic composition $\left(\delta^{34} S\right)$ of sulphide minerals in the Huanuni deposit, relative to the VCDT standard.

\section{Discussion}

\subsection{Paragenetic Constraints on the Genesis of the Deposit}

The three hypogene stages of mineralisation that are characterised in all the studied areas of the Huanuni deposit are in accordance with the basic scheme of mineralisation that was already deduced upon the systematic reconnaissance of Bolivian tin deposits [8,12-14]. This implies two initial stages of mineralisation rich in cassiterite and base-metal sulphides, and a late stage that is characterised by the occurrence of stannite-kësterite and sulphosalts. Among the available fluid inclusion studies in this deposit [15-17], the closest to a systematic attempt relies in data from the Keller and Bandy vein groupings toward the peripheral zones of the mineralised area [16]. The latter study reported temperatures of homogenisation up to $425^{\circ} \mathrm{C}$ (mostly at about $360^{\circ} \mathrm{C}$ ) and low to moderate salinities (up to $11.6 \mathrm{wt} . \% \mathrm{NaCl}$ equiv.), although saline brines up to $26 \mathrm{wt} . \% \mathrm{NaCl}$ equiv. have also been reported [17]. However, paragenetic sequences that are similar to those determined in the Huanuni deposit have been described to occur as a response to a generalised decrease in temperature of mineralising fluids in other deposits of the Bolivian tin belt $[8,14]$.

The occurrence of schorl and potassium feldspar in stage 2 in the central part of the deposits (Pozokoni area) suggests that (A) such area recorded the influx of fluids with higher temperatures than in the peripheral portions of the deposit, and (B) stage 2 represents an increase in temperature of mineralising fluids with respect to stage 1, as already suggested in reference [14]. In spite of the scarce geothermometric determinations available for this deposit, the association between schorl and relatively high temperatures of mineralising hydrothermal fluids is sustained empirically in several types of mineral deposits [41-46]. In these types of deposits, which include porphyry-type and Sn-W deposits, schorl-bearing mineral associations formed generally at temperatures that range between $>300^{\circ} \mathrm{C}$ and $<500^{\circ} \mathrm{C}$. Such range of temperatures is in accordance with the scarce available data from fluid inclusions, in which temperatures of homogenisation were determined to range between $<200^{\circ} \mathrm{C}$ and $425^{\circ} \mathrm{C}[4,16,17]$. Such relatively high temperatures are also congruent with the occurrence of the association between dickite and kaolinite (argillic or advanced argillic alteration assemblages) in this deposit [16,39], and the occurrence of pyrophyllite documented in this study. In addition, such association constitutes a typical indicator of the occurrence of deep hypogene high sulphidation fluids in the porphyry to epithermal environment [47-49]. Therefore, the concurrence of (A) schorl (Figure 4A-D), (B) potassium feldspar as vein material (Figure 3B-D), which may stand for potassic 
alteration assemblages, and (C) dickite-bearing argillic to advanced argillic alteration assemblages in the Huanuni deposits may altogether denote the influx of magmatic ore-bearing fluids, particularly in the central part of the district (Pozokoni area).

The mineral distribution in the deposit differs between the central and peripheral areas. As already stated, schorl occurs in the central part of the Huanuni district, which also monopolises the occurrence of wolframite, $\mathrm{Ni}$ and Co minerals. The central and the La Suerte area are the richest in tin in the deposit. In the central area (Veta Grande vein) the highest contents in $\mathrm{Nb}-\mathrm{Ta}$ in the deposit were found, in cassiterite. Stannite, a common mineral in the central area shows significant In and Ga contents. In contrast, the peripheral zones are rich in silver sulfosalts and sphalerite-Which, unlike the central area, is generally iron-rich and a major indium carrier (particularly in the Bonanza area), and also contains abundant chalcopyrite disease textures. Besides, in the Bonanza area were found rare stetindite-(Ce), a cerium silicate, and a supergene indium carbonate, unknown as a mineralogical species. The differential distribution of ore minerals and contents in critical elements may then be associated with a temperature zonation, or with differential distribution of magmatic fluids in the Huanuni district. The epithermal-to-porphyry transition environment that is sketched above does not mean that this deposit belongs precisely to this environment-Alternatively, such reference is only used to provide an idea for the thermal and mineralogical framework in which the Huanuni deposit can be located. Upon the available thermometric and paragenetic constraints, this framework can be tentatively described as xenothermal $[22,50]$ or mesothermal. No evidence hitherto has been produced that sustains the idea that deeper porphyry-style mineralisation may exist in this deposit, and no deep or systematic drilling in the area has been undertaken either. However, to the present extent of research in the Huanuni deposit, the occurrence of schorl and dickite [16,39] in the central part of the deposit but not in the peripheral areas suggests that the central part would have experienced the upwelling of fluids at higher temperatures than the peripheral part. Therefore, any possible exploration endeavours that aim for high-temperature associations or a blind stock that would have hypothetically fed the paleo-hydrothermal system should be focused on the central part of the deposit. The possibility of an actual temperature zonation (with temperature decreasing outwards, from the central to the peripheral mineralised areas) or of preferential distribution of ore-bearing magmatic fluids needs to be addressed in further studies, i.e., fluid inclusion, $\mathrm{O}$ and $\mathrm{H}$ stable isotope, and fluid geochemistry studies.

Beyond the relatively limited collection of variables with which it is possible to characterise a given ore deposit as part of a deposit type or family, the Bolivian tin deposits (at least those formed during the Neogene) stand collectively as a mineral system, in the sense of references [51-53]. Recent studies in critical element-bearing deposits of the region [4-10], along with this one, describe deposits whose depositional models vary between xenothermal or mesothermal (i.e., Huari Huari, Huanuni) and epithermal (i.e., Poopó), whereas others (i.e., Ánimas-Chocaya-Siete Suyos) exhibit intermediate characteristics between those. The ore mineralogy and paragenetic sequences in all these deposits are very similar, as already noticed in early works in the region [12-14]. The contents in critical elements (i.e., $\mathrm{In}, \mathrm{Ga}, \mathrm{Ge}$ ) in these deposits are also variable, normally in the form of minor or trace contents in sphalerite, cassiterite, stannite-kësterite, and a number of sulphides and sulphosalts [5,6,8-10], rarely as minerals in which such elements are stoichiometric constituents like petrukite, sakuraite or argyrodite. In the case of Huanuni, indium also occurs exceptionally as a constituent of a supergene carbonate with unknown mineralogical characteristics (Figure 6F). It is not idly that we speak of the Neogene Bolivian tin deposits as a mineral system, and future endeavours in the region will benefit from the use of this conceptual framework.

\subsection{Mineralogy and Distribution of Critical Elements}

Upon the available determinations of the chemical variation of minerals in the Huanuni deposit, major carriers of strategic metals are distributed as follows: (A) for niobium and tantalum, stage-1 cassiterite from the Central area, (B) for indium, stage-1 cassiterite from the Central area, stage-3 stannite-kësterite from the Central area and sphalerite in both the peripheral and central areas (stages 
2), (C) for germanium, albeit in trace concentrations, stage-3 stannite-kësterite from the Central area, and (D) for gallium, albeit in trace concentrations, stage- 1 cassiterite and stage- 3 stannite-kësterite from the Central area. The most relevant among critical elements in the Huanuni deposit is indium, as it occurs in different minerals (cassiterite, sphalerite and stannite), in all stages of mineralisation, and in both the central and peripheral mineralised areas. The occurrence of monazite and stetindite-(Ce) in the peripheral mineralised areas does not stand, in principle, for a cerium anomaly in the deposit, but raises a warning flag nonetheless. High cadmium contents in sphalerite and wurtzite (Table S1) constitute an additional feature in the district to be highlighted, not as a critical element but due to its potential as an environmentally hazardous metal. The occurrence of significant amounts of indium along with high contents in $\mathrm{Cd}$ and $\mathrm{Ga}$ in association with a variety of sulphide-bearing parageneses has been suggested to have a high affinity with magmatic-hydrothermal processes [54,55]. Despite the soundness of data in the study, further research that addresses the distribution of critical elements at greater detail would be desirable.

In summary, the central area of the Huanuni district emerges as the most prospective one in terms of its potential in strategic elements. Another indium carrier in the deposit is a carbonate (a possible new mineral) that occurs as a supergene mineral within micro-fractures in In-bearing sphalerite. This would be indicative for the mobilisation of indium in supergene conditions, in which it apparently behaves as a rather immobile element [56].

A different matter is how to deal with critical elements in this deposit (particularly In) metallurgically if they were ever to be aimed and specialised literature, however scarce, already exists on this matter [57,58]. Also, relatively high Cd contents in sphalerite and wurtzite (Table S1) can be a major environmental liability that must not be overlooked during mineral processing.

\subsection{Sources for Sulphur}

Previously published $\delta^{34} \mathrm{~S}_{\mathrm{VCDT}}$ data for sulphides in the Huanuni deposit are very scarce and ranged between $-5.5 \%$ o and $-3.5 \%$ o [59], whereas the data obtained in this study range between $-7.5 \%$ o and $1.0 \%$. Such range of data is similar to those in the Oruro-Potosí region of the central Andean Tin Belt $[9,56]$, in which the Huanuni deposit is found, and in other tin deposits elsewhere [60], and in intermediate- to low-sulphidation epithermal deposits in Cordilleran environments [61-63]. A range of values as the one obtained in this study is typically described to correspond to sulphur that was derived from a sedimentary or metasedimentary, and magmatic source (either from a direct contribution or by scavenging of sulphur from magmatic rocks). On one hand, sedimentary or metasedimentary sources for sulphur in the mineralisation are further supported by the dominantly metasedimentary character of host rocks in the study area and in the region where it is located. On the other hand, a magmatic source for sulphur is consistent with derivation from a magmatic-hydrothermal fluid (see sections above). Yet, it is possible that the obtained values come solely from magmatic sources, such magmas would necessarily involve different degrees of crustal assimilation or their generation after the partial melting of sedimentary rocks [64]. Such is the case of the magmas associated with Cenozoic tin mineralisation of the Eastern Andes, which mostly resulted from sediment melting in a thickened continental crust. This circumstance explains their distinctive peraluminous and reduced signature, thus belonging to the S-type, ilmenite-series $[2,65,66]$.

A noticeable feature in the Huanuni deposit is the strikingly different ranges in $\delta^{34} S$ data between the central and peripheral areas of the deposit: most of the data from the central mineralised area cluster between $-7 \%$ and $-5 \%$, whereas in peripheral areas they cluster between $-2 \%$ and $1 \%$ o (Figure 11 ). Thus, the apparently bimodal distribution of $\delta^{34} S$ data in the Huanuni deposit actually corresponds to the sum of two nearly unimodal distributions of data from different mineralised areas. A magmatic source for sulphur arises dominantly in the peripheral areas, whereas the compositions that suggest a higher proportion of sedimentary or metasedimentary sulphur are found in the central area of the deposit. As suggested in earlier sections in this paper, the central area contains mineral associations that are suggestive of the occurrence of hot and acidic magmatic fluids, which would seemingly 
contradict such interpretation (see also [21]). However, sources for sulphur are not necessarily similar to the sources for mineralising fluids and both features above are geologically compatible. In this case, sedimentary or metasedimentary sources for sulphur would be compatible with magmatic sources for hot and acidic magmatic mineralising fluids because such fluids would be, in principle, very efficient in leaching sulphur from the country rocks. Such a process would have masked the (presumed) dominantly $\delta^{34} \mathrm{~S}$ values within ranges that would typically denote magmatic sources. In contrast, the range of $\delta^{34} S$ data that was obtained in peripheral areas of the Huanuni deposit reflects magmatic sources for sulphur more clearly than the central area. A plausible reason for such feature could be that mineralising fluids in peripheral areas were cooler and less reactive with country rocks than in the central area, thus mobilising a lower proportion of sedimentary or metasedimentary sulphur. The most negative $\delta^{34} S$ values in similar isotopic zonation patterns have been effectively associated with the occurrence of oxidised magmatic-hydrothermal fluids in the porphyry-to-epithermal environment and with their prospectiveness [66-68]. Zonation in the isotopic composition of sulphur in sulphides at any scale (from single-grain to deposit, district or semi-regional scales) is not an uncommon feature in many different types of ore deposits and responds to a few reasons [59,66-75]. Such isotopic zonation at a district level in Huanuni constitutes an additional feature that would be necessary to test in future endeavours. For further studies, the coincidental distribution of (A) evidence for relatively hot and acidic fluids (from possibly ultimate magmatic sources, at least as an exploratory idea), (B) the distribution of tin mineralisation, (C) the occurrence of low $\delta^{34} S$ values, and (D) the occurrence of promising to high contents in critical/strategic elements, needs to be evaluated in terms of a possible common causation.

\section{Conclusions}

The polymetallic deposits of Huanuni (Sn-, Zn- and Ag-rich) in southwest Bolivia, within the Bolivian Tin Belt, represent one of the largest tin resources in the world but also bear some potential in strategic metals such as In, Ga and in lesser amounts, Ge. The paragenetic constraints in this deposit suggest that its formation could have formed in "mesothermal" or "xenothermal" environments.

This study allowed for grouping its complex mineralogy into three hypogene stages of mineralisation within three main mineralised areas (a central and two peripheral areas), and a supergene stage. Stages 1 and 2 are described as base metal-rich cassiterite-bearing stages, and stage 3 is a silver-rich stage. Stage 2 is the main carrier of schorl, tin minerals and In-bearing sphalerite in the deposit, as well as minor Ni, Co and Ce minerals, in the central area of the deposit. The occurrence of schorl in stage 2 (central area) and the association of dickite and kaolinite in the hydrothermal alteration suggests that in the formation of the deposit concurred relatively high temperature and low $\mathrm{pH}$ hydrothermal fluids.

The differential distribution of minerals in the Huanuni deposit, coupled with the contrasting $\delta^{34} S_{V C D T}$ values for sulphides, between the central and the peripheral areas of the deposit suggests a temperature zonation during the formation of the deposit, with higher temperatures in the central area than in the peripheral ones. Such areas may also have experienced differential entrainment of magmatic ore-bearing fluids and sulphur during mineralisation processes. The main sources for sulphur are magmatic and sedimentary/metasedimentary, and both are supported by $\delta^{34} \mathrm{~S}_{\mathrm{VCDT}}$ data as well as further geological evidence.

Among critical metals, In arises as the most relevant one in this deposit-It occurs in stage-1 cassiterite from the central area, stage-3 stannite-kësterite from the central area and in sphalerite in both the central (stage 3) and peripheral areas (stages 2 and 3). Among In-bearing minerals, an indium carbonate (a possible new mineral) occurs as part of supergene associations and formed after In-bearing sphalerite. Other critical metals in relevant concentrations are $\mathrm{Nb}$-Ta in stage- 1 cassiterite from the central area, Ge in stage-3 stannite-kësterite from the central area, and traces of Ga in stage-1 cassiterite and stage-3 stannite-kësterite from the central area. 
Supplementary Materials: The following are available online at http://www.mdpi.com/2075-163X/9/12/753/s1, Table S1: EPMA analyses in selected minerals of the Huanuni deposit, Table S2: Trace-element analyses of stannite (stn), arsenopyrite (apy) and cassiterite (cst), expressed in ppm. Data obtained by LA-ICP-MS. Values below detection limit are shown as " $<\mathrm{dl}^{\prime}$.

Author Contributions: Conceptualization: J.-C.M., L.T., A.C. (Antoni Camprubí), P.A., O.R.A.-B.; fieldwork: B.T., J.-C.M., L.T., Á.M.; methodology and analysis: A.C. (Andreu Cacho), J.C.M., L.T., M.C.-O., D.A., M.C., P.A., E.T.; writing-original draft preparation: A.C. (Antoni Camprubí), A.C. (Andreu Cacho); writing-review and editing: A.C. (Antoni Camprubí), J.-C.M., L.T., M.C.-O.

Funding: This study benefitted from the budged granted by the Generalitat de Catalunya (Autonomous Government of Catalonia) to the Consolidated Research Group SGR 444, the AECID project A3/042750/11, CCD project 2015-U008, and the Peruvian project 107-2018-FONDECYT-BM-IADT-AV. Additional funding was provided by the Fundació Pedro Pons (UB), and by the Instituto de Geología (UNAM) by means of its yearly personal budget allocation. This study used instrumentation funded by the ARC Centre of Excellence for Core to Crust Fluid Systems (CE110001017) of Excellence for Core to Crust Fluid Systems, the ARC LIEF and DEST Systemic Infrastructure Grants, Macquarie University, NCRIS AuScope and Industry.

Acknowledgments: The Bolivian State Mining Company (Corporación Minera de Bolivia-COMIBOL) granted its permission to the authors to access the studied mines and to perform the necessary sampling; Ramiro Condori, Néstor Guevara, and all individuals at COMIBOL are cordially thanked for their kind and efficient help furing field work. Technical assistance was kindly provided by Xavier Alcobé, Maria Barba (XRD), Eva Prats, Aránzazu Villuendas (SEM-EDS), Xavier Llovet (EPMA), all of them at the Centres Científics i Tecnologics of the Universitat de Barcelona. The authors would like to acknowledge William L. Griffin and Suzanne Y. O'Reilly for their scientific insight, and William Powell, Yoann Gréau, Olivier Alard and Sarah Gain for their help with the LA-ICP-MS analyses at the GAU (Macquarie University). The authors acknowledge the corrections and suggestions of three anonymous referees, which helped to improve this paper.

Conflicts of Interest: To the knowledge of the authors, no conflicts of interest whatsoever exist between them and any other individuals with regard to the contents of this paper. The funders had no role in the design of the study, in the collection, analyses, or interpretation of data, in the writing of the manuscript, or in the decision to publish the results.

\section{References}

1. Turneaure, F.S. The Bolivian tin-silver province. Econ. Geol. 1971, 66, 215-225. [CrossRef]

2. Lehmann, B.; Ishihara, S.; Michel, H.; Miller, J.; Rapela, C.; Sanchez, A.; Tistl, M.; Winkelmann, L. The Bolivian tin province and regional tin distribution in the central Andes: A reassessment. Econ. Geol. 1990, 85, 1044-1058. [CrossRef]

3. Mlynarczyk, M.S.J.; Williams-Jones, A.E. The role of collisional tectonics in the metallogeny of the Central Andean tin belt. Earth Planet. Sci. Lett. 2005, 240, 656-667. [CrossRef]

4. Ishihara, S.; Murakami, H.; Marquez-Zavalia, M.F. Inferred indium resources of the Bolivian tin-polymetallic deposits. Resour. Geol. 2011, 61, 174-191. [CrossRef]

5. Jiménez-Franco, A.; Alfonso, P.; Canet, C.; Trujillo, J.E. Mineral chemistry of In-bearing minerals in the Santa Fe mining district, Bolivia. Andean Geol. 2018, 45, 410-432. [CrossRef]

6. Murakami, H.; Ishihara, S. Trace elements of indium-bearing sphalerite from tin-polymetallic deposits in Bolivia, China and Japan: A femto-second LA-ICPMS study. Ore Geol. Rev. 2013, 53, 223-243. [CrossRef]

7. Schwarz-Schampera, U.; Herzig, P.M. Indium: Geology, Mineralogy and Economics; Springer: Heidelberg, Germany, 2002.

8. Torró, L.; Cazorla, M.; Melgarejo, J.C.; Camprubí, A.; Tarrés, M.; Gemmrich, L.; Campeny, M.; Castillo-Oliver, M.; Artiaga, D.; Torres, B.; et al. Indium mineralization in the volcanic dome-hosted Ánimas-Chocaya-Siete Suyos polymetallic deposit, Potosí, Bolivia. Minerals 2019, 9, 604. [CrossRef]

9. Torró, L.; Melgarejo, J.C.; Gemmrich, L.; Mollinedo, D.; Cazorla, M.; Martínez, Á.; Pujol-Solà, N.; Farré de Pablo, J.; Camprubí, A.; Artiaga, D.; et al. Spatial and temporal controls on the distribution of indium in xenothermal vein deposits: The Huari Huari district, Potosí, Bolivia. Minerals 2019, 9, 304. [CrossRef]

10. Torres, B.; Melgarejo, J.C.; Torró, L.; Camprubí, A.; Castillo-Oliver, M.; Artiaga, D.; Campeny, M.; Tauler, E.; Jiménez-Franco, A.; Alfonso, P.; et al. The Poopó Polymetallic Epithermal Deposit, Bolivia: Mineralogy, Genetic Constraints, and Distribution of Critical Elements. Minerals 2019, 9, 472. [CrossRef]

11. European Commission, Critical Raw Materials. Available online: https://ec.europa.eu/growth/sectors/rawmaterials/specific-interest/critical_en (accessed on 1 April 2019). 
12. Turneaure, F.S. A comparative study of major ore deposits of central Bolivia. Part, I. Econ. Geol. 1960, 55, 217-254. [CrossRef]

13. Turneaure, F.S. A comparative study of major ore deposits of central Bolivia. Part II. Econ. Geol. 1960, 55, 574-606. [CrossRef]

14. Kelly, W.C.; Turneaure, F.S. Mineralogy, paragenesis, and geothermometry of the tin and tungsten deposits of the eastern Andes, Bolivia. Econ. Geol. 1970, 65, 609-680. [CrossRef]

15. Sugaki, A.; Kojima, S.; Shimada, N. Fluid inclusion studies of the polymetallic hydrothermal ore deposits in Bolivia. Miner. Deposita 1988, 23, 9-15. [CrossRef]

16. Arce, O.; Nambu, M. Fluid inclusion study in the Huanuni mine, Bolivia. J. Min. Mater. Process. Inst. Jpn. 1989, 105, 1073-1078. [CrossRef]

17. Müller, B.; Frischknecht, R.; Seward, T.; Heinrich, C.; Camargo Gallegos, W. A fluid inclusion reconnaissance study of the Huanuni tin deposit (Bolivia), using LA-ICP-MS micro-analysis. Miner. Depos. 2001, 36, 680-688. [CrossRef]

18. Ahlfeld, F.; Schneider-Scherbina, A. Los yacimientos minerales y de hidrocarburos de Bolivia. Bol. Dept. Nac. Geol. La Paz 1964, 5, 388.

19. Lehmann, B. Metallogeny of Tin: Springer-Verlag (Lecture Notes in Earth Sciences Series, 31); Springer: Berlin/Heidelberg, Germany, 1990; p. 211.

20. Redwood, S. The Metallogeny of the Bolivian Andes. Vancouver, British Columbia, University of British Columbia; Mineral Deposit Research Unit 15: Ottawa, ON, Canada, 1993; p. 59.

21. Heuschmidt, B.; Bellot de la Torre, J.; Miranda Angles, V.; Claure Zapata, M. Las Areas Prospectivas de Bolivia para yacimientos metalíferos. Boletín del Servicio Nacional de Geología y Minería 2002, 30, 1-154.

22. Suarez-Soruco, R. Compendio de Geología de Bolivia; Servicio Nacional de Geología y Minería, Yacimientos Petrolíferos Fiscales Bolivianos: Cochabamba, Bolivia, 2000; pp. 39-76.

23. McQuarrie, N.; DeCelles, P.G. Geometry and structural evolution of the Central Andean backthrust belt, Bolivia. Tectonics 2001, 20, 669-692. [CrossRef]

24. Redwood, S.D.; Rice, C.M. Petrogenesis of Miocene basic shoshonitic lavas in the Bolivian Andes and implications for hydrothermal gold, silver and tin deposits. J. South. Am. Earth Sci. 1997, 10, $203-221$. [CrossRef]

25. Morgan VI, G.B.; London, D.; Luedke, R.G. Petrochemistry of Late Miocene peraluminous silicic volcanic rocks from the Morococala field, Bolivia. J. Petrol. 1998, 39, 601-632. [CrossRef]

26. De Silva, S.; Kay, S.M. Turning up the heat: High-flux magmatism in the Central Andes. Elements 2018, 9 , 245-250. [CrossRef]

27. Wörner, G.; Mamani, M.; Blum-Oeste, M. Magmatism in the Central Andes. Elements 2018, 9, $237-244$. [CrossRef]

28. Koeppen, R.P.; Smith, R.L.; Kunk, M.J.; Flores, A.M.; Luedke, R.G.; Sutter, J.F. The Morococala volcanics: Highly peraluminous rhyolite ash flow magmatism in the Cordillera Oriental, Bolivia. Geol. Soc. Am. Abstr. Programs 1987, 19, 731.

29. Benedetto, J.L.; Sánchez, T.M.; Brusa, E.D. Las cuencas silúricas de América Latina. In Paleozoico Inferior de Ibero-América; Gutiérrez, J.G., Saavedra, M.J., Rábano, I., Eds.; Universidad de Extremadura: Badajoz, Spain, 1992; pp. 119-148.

30. Sempere, T. Phanerozoic evolution of Bolivia and adjacent regions. In Petrole $\mu m$ Basins of South America; Tankard, A.J., Suárez, R., Welsink, H.J., Eds.; AAPG Mem: Tulsa, OK, USA, 1995; pp. 207-230.

31. Arce-Burgoa, O. Guía de los Yacimientos metalíferos de Bolivia; Minera San Cristóbal, S.A., Ed.; SPC Impresiones S.A.: La Paz, Bolivia, 2009; pp. 4-12.

32. Cacho, A.; Melgarejo, J.C.; Torró, L.; Arqués, L.; Martínez, Á.; Torres, B.; Artiaga, D.; Tauler, E.; Condori, R.; Guevara, N.; et al. Huanuni, Bonanza and La Suerte mines: Mineralogy, geochemistry and structure. In Mineral Resources in A Sustainable World, 13th SGA Biennial Meeting 2015; André-Meyer, A.-S., Cathelineau, M., Muchez, P., Pirard, E., Sindern, S., Eds.; Proceedings: Nancy, France, 2015; pp. 691-694.

33. Jochum, K.P.; Weis, U.; Stoll, B.; Kuzmin, D.; Yang, Q.; Raczek, I.; Jacob, D.E.; Stracke, A.; Birbaum, K.; Frick, D.A.; et al. Determination of reference values for NIST SRM 610-617 glasses following ISO guidelines. Geostand. Geoanal. Res. 2011, 35, 397-429. [CrossRef] 
34. Van Achterbergh, E.; Ryan, C.G.; Jackson, S.E.; Griffin, W.L. Data reduction software for LA-ICP-MS: Appendix. In Laser Ablation-ICP-Mass Spectrometry in the EARTH Sciences: Principles and Applications. The Mineralogical Association of Canada Short Course Series; Sylvester, P.J., Ed.; Mineralogical Association of Canada, St. Johns: Quebec, QC, Canada, 2001; pp. 239-243.

35. Griffin, W.L.; Powell, W.J.; Pearson, N.; O’Reilly, S.Y. GLITTER: Data reduction software for laser ablation ICP-MS. In Laser Ablation-ICP-MS in the Earth Sciences. Mineralogical Association of Canada Short Course Series; Sylvester, P.J., Ed.; Mineralogical Association of Canada, St. Johns: Quebec, QC, Canada, 2008; pp. 204-207.

36. Baker, T.; Mustard, R.; Brown, V.; Pearson, N.; Stanley, C.R.; Radford, N.W.; Butler, I. Textural and chemical zonation of pyrite at Pajingo: A potential vector to epithermal gold veins. Geochem Explor. Environ. Anal. 2004, 6, 283-293. [CrossRef]

37. Wilson, S.A.; Ridley, W.I.; Koenig, A.E. Development of sulfide calibration standards for the laser ablation inductively-coupled plasma mass spectrometry technique. J. Anal. At. Spectrom. 2002, 17, 406-409. [CrossRef]

38. Santivañez, R. Mineralogía y termometría de las vetas Keller (Huanuni). Memoria del Coloquio del IGE. Conv. UMSA-JICA 1986, 2, 131-157.

39. Mindat.org, Huanuni, Dalence Province, Oruro, Bolivia. Available online: https://www.mindat.org/loc14512.html (accessed on 28 February 2019).

40. Anthony, J.W.; Bideaux, R.A.; Bladh, K.W.; Nichols, M.C. Handbook of Mineralogy, Volume IV; Arsenates, Phosphates, Vanadates; Mineral Data Publishing: Tucson, AZ, USA, 2000; p. 680.

41. Grant, J.N.; Halls, C.; Avila, W.; Avila, G. Igneous geology and the evolution of hydrothermal systems in some sub-volcanic tin deposits of Bolivia. Geol. Lond. Soc. Spec. Publ. 1977, 7, 117-126. [CrossRef]

42. Krienitz, M.-S.; Trumbull, R.B.; Hellmann, A.; Kolb, J.; Meyer, F.M.; Wiedenbeck, M. Hydrothermal gold mineralization at the Hira Buddini gold mine, India: Constraints on fluid evolution and fluid sources from boron isotopic compositions of tourmaline. Miner. Deposita 2008, 43, 421-434. [CrossRef]

43. Baksheev, I.A.; Tikhomirov, P.L.; Yapaskurt, V.O.; Vigasina, M.F.; Prokof'ev, V.Y.; Ustinov, V.I. Tourmaline of the Mramorny tin cluster, Chukotka peninsula, Russia. Can. Mineral. 2009, 47, 1177-1194. [CrossRef]

44. Prokofiev, V.; Baksheev, I.; Zorina, L.; Belyatsky, B.; Ustinov, V.; Krivitskaya, N. Tourmalinization at the Darasun goldfield, Eastern Transbaikalia: Compositional, fluid inclusion and isotopic constraints. Geosci. Front. 2012, 3, 59-71. [CrossRef]

45. Marks, M.A.W.; Marschall, H.R.; Schühle, P.; Guth, A.; Wenzel, T.; Jacob, D.E.; Barth, M.; Markl, G. Trace element systematics of tourmaline in pegmatitic and hydrothermal systems from the Variscan Schwarzwald (Germany): The importance of major element composition, sector zoning, and fluid or melt composition. Chem. Geol. 2013, 344, 73-90. [CrossRef]

46. Huang, S.; Song, Y.; Hou, Z.; Xue, C. Chemical and stable isotopic (B, H, and O) compositions of tourmaline in the Maocaoping vein-type $\mathrm{Cu}$ deposit, western Yunnan, China: Constraints on fluid source and evolution. Chem. Geol. 2016, 439, 173-188. [CrossRef]

47. Hedenquist, J.W.; Arribas, A.; Jr Reynolds, T.J. Evolution of an intrusive-centered hydrothermal system: Far Southwest-Lepanto porphyry and epithermal Cu-Au deposits, Philippines. Econ. Geol. 1998, 93, 373-404. [CrossRef]

48. Milu, V.; Milési, J.-P.; Leroy, J.L. Rosia Poieni copper deposit, Apuseni Mountains, Romania: Advanced argillic overprint of a porphyry system. Min. Deposita 2004, 39, 173-188. [CrossRef]

49. Longo, A.A.; Dilles, J.H.; Grunder, A.L.; Duncan, R. Evolution of calc-alkaline volcanism and associated hydrothermal gold deposits at Yanacocha, Peru. Econ. Geol. 2010, 105, 1191-1241. [CrossRef]

50. Sugaki, A.; Ueno, H.; Shimada, N.; Kitakaze, A.; Hayashi, K.; Shima, H.; Sanjines, O.; Saavedra, A. Geological Study on Polymetallic Hydrothermal Deposits in the Oruro District, Bolivia. Sci. Rep. Tohoku Univ. Ser. III 1981, 15, 1-52.

51. Hronsky, J.M.A.; Groves, D.I.; Loucks, R.R.; Begg, G.C. A unified model for gold mineralisation in accretionary orogens and implications for regional-scale exploration targeting methods. Miner. Dep. 2012, 47, 339-358. [CrossRef]

52. McCuaig, T.C.; Hronsky, J.M.A. The mineral system concept: The key to exploration targeting. Soc. Econ. Geol. Spec. Publ. 2014, 18, 153-175. [CrossRef] 
53. Huston, D.L.; Mernagh, T.P.; Hagemann, S.G.; Doublier, M.P.; Fiorentini, M.; Champion, D.C.; Jaques, A.L.; Czarnota, K.; Cayley, R.; Skirrow, R.; et al. Tectono-metallogenic systems-The place of mineral systems within tectonic evolution, with an emphasis on Australian examples. Ore Geol. Rev. 2016, 76, 168-210. [CrossRef]

54. King, J.; Williams-Jones, A.E.; Van Hinsberg, V.; Williams-Jones, G. High-sulfidation epithermal pyrite-hosted $\mathrm{Au}(\mathrm{Ag}-\mathrm{Cu})$ ore formation by condensed magmatic vapors on Sangihe Island, Indonesia. Econ. Geol. 2014, 109, 1705-1733. [CrossRef]

55. Andersen, J.C.Ø.; Stickland, R.J.; Rollinson, G.K.; Shail, R.K. Indium mineralisation in SW England: Host parageneses and mineralogical relations. Ore Geol. Rev. 2016, 78, 213-238. [CrossRef]

56. Lopez, L.; Jovic, S.M.; Guido, D.M.; Permuy-Vidal, C.; Páez, G.N.; Ruiz, R. Geochemical distribution and supergene behavior of indium at the Pingüino epithermal polymetallic vein system, Patagonia, Argentina. Ore Geol. Rev. 2015, 64, 747-755. [CrossRef]

57. Werner, A.; Haseneder, R.; Repke, J.-U. pH-dependent retention measurements of indium and germanium with nanofiltration membranes. Freib. Online Geosci. 2015, 40, 136-137.

58. Liu, Y.; Fan, Y.-Y.; Qi, J.-F.; Tian, L.; Zhang, T.-A. Research on sulfur conversion behavior in oxygen pressure acid leaching process of high indium sphalerite. In Materials Processing Fundamentals 2018. TMS 2018. The Minerals, Metals \& Materials Series; Lambotte, G., Lee, J., Allanore, A., Wagstaff, S., Eds.; Springer: Berlin/Heidelberg, Germany, 2018; pp. 199-208.

59. Sugaki, A.; Ueno, H.; Hayashi, K. Sulfur isotope reconnaissance of Bolivian hydrothermal deposits. Min. Geol. 1990, 40, 299-312.

60. Xiong, Y.Q.; Shao, Y.J.; Mao, J.W.; Wu, S.C.; Zheng, M.H. The polymetallic magmatic-hydrothermal Xiangdong and Dalong systems in the $\mathrm{W}-\mathrm{Sn}-\mathrm{Cu}-\mathrm{Pb}-\mathrm{Zn}-\mathrm{Ag}$ Dengfuxian orefield, SE China: Constraints from geology, fluid inclusions, $\mathrm{H}-\mathrm{O}-\mathrm{S}-\mathrm{Pb}$ isotopes, and sphalerite $\mathrm{Rb}-\mathrm{Sr}$ geochronology. Miner. Deposita 2019. [CrossRef]

61. Camprubí, A.; Cardellach, E.; Canals, À.; Lucchini, R. The La Guitarra Ag-Au low sulfidation epithermal deposit, Temascaltepec district, Mexico: Fluid inclusion and stable isotope data. In New mines and discoveries in Mexico and Central America; Albinson, T., Nelson, C.E., Eds.; Society of Economic Geologists Special Publication: Littleton, CO, USA, 2001; pp. 159-185.

62. Camprubí, A.; González-Partida, E.; Torres-Tafolla, E. Fluid inclusion and stable isotope study of the Cobre-Babilonia polymetallic epithermal vein system, Taxco district, Guerrero, Mexico. J. Geochem. Explor. 2006, 89, 33-38. [CrossRef]

63. Mango, H.; Arehart, G.; Oreskes, N.; Zantop, H. Origin of epithermal Ag-Au-Cu-Pb-Zn mineralization in Guanajuato, Mexico. Miner. Deposita 2014, 49, 119-143. [CrossRef]

64. Seal, I.R. Sulfur isotope geochemistry of sulfide minerals. Rev. Mineral. Geochem. 2006, 61, $633-677$. [CrossRef]

65. Ishihara, S. The granitoid series and mineralization. Econ. Geol. 1981, 75, 458-484.

66. Lehmann, B.; Dietrich, A.; Heinhorst, J.; Metrich, N.; Mosbah, M.; Palacios, C.; Schneider, H.J.; Wallianos, A.; Webster, J.; Winkelmann, L. Boron in the Bolivian tin belt. Mineral. Dep. 2000, 35, 223-232. [CrossRef]

67. Frikken, P.H.; Cooke, D.R.; Walshe, J.L.; Archibald, D.; Skarmeta, J.; Serrano, L.; Vargas, R. Mineralogical and isotopic zonation in the Sur-Sur tourmaline breccia, Río Blanco-Los Bronces Cu-Mo deposit, Chile: Implications for ore genesis. Econ. Geol. 2005, 100, 935-961. [CrossRef]

68. Wilson, A.J.; Cooke, D.R.; Harper, B.J.; Deyell, C.L. Sulfur isotopic zonation in the Cadia district, southeastern Australia: Exploration significance and implications for the genesis of alkalic porphyry gold-copper deposits. Mineral. Dep. 2007, 42, 465-487. [CrossRef]

69. Zukowski, W.; Cooke, D.R.; Deyell, C.L.; McInnes, P.; Simpson, K. Genesis and exploration implications of epithermal gold mineralization and porphyry-style alteration at the Endeavour 41 prospect, Cowal District, New South Wales, Australia. Econ. Geol. 2014, 109, 1079-1115. [CrossRef]

70. Ireland, T.; Large, R.R.; McGoldrick, P.; Blake, M. Spatial distribution patterns of sulfur isotopes, nodular carbonate, and ore textures in the McArthur River (HYC) Zn-Pb-Ag deposit, Northern Territory, Australia. Econ. Geol. 2004, 99, 1687-1709. [CrossRef]

71. Kelley, D.L.; Kelley, K.D.; Coker, W.B.; Caughlin, B.; Doherty, M.E. Beyond the obvious limits of ore deposits: The use of mineralogical, geochemical, and biological features for the remote detection of mineralization. Econ. Geol. 2006, 101, 729-752. [CrossRef] 
72. Bastrakov, E.N.; Skirrow, R.G.; Davidson, G.J. Fluid evolution and origins of iron oxide Cu-Au prospects in the Olympic Dam district, Gawler Craton, South Australia. Econ. Geol. 2006, 102, 1415-1440. [CrossRef]

73. Cazañas, X.; Alfonso, P.; Melgarejo, J.C.; Proenza, J.A.; Fallick, A.E. Geology, fluid inclusion and sulphur isotope characteristics of the El Cobre VHMS deposit, Southern Cuba. Mineral. Dep. 2008, 43, 805-824. [CrossRef]

74. Ingham, E.S.; Cook, N.J.; Cliff, J.; Ciobanu, C.L.; Huddleston, A. A combined chemical, isotopic and microstructural study of pyrite from roll-front uranium deposits, lake Eyre basin, South Australia. Geochim. Cosmochim. Acta 2014, 125, 440-465. [CrossRef]

75. Velasco-Acebes, J.; Tornos, F.; Kidane, A.T.; Wiedenbeck, M.; Velasco, F.; Delgado, A. Isotope geochemistry tracks the maturation of submarine massive sulfide mounds (Iberian Pyrite Belt). Mineral. Dep. 2019. [CrossRef]

(C) 2019 by the authors. Licensee MDPI, Basel, Switzerland. This article is an open access article distributed under the terms and conditions of the Creative Commons Attribution (CC BY) license (http://creativecommons.org/licenses/by/4.0/). 